\title{
Uma Mente Embebida na Cultura
}

\author{
[A Mind Embedded in Culture]
}

\section{Paulo C. Abrantes*}

Resumo: Este artigo investiga o papel que a cultura desempenha em diferentes cenários para a evolução humana. A primeira parte expõe os elementos básicos de uma explicação da capacidade da mente humana para atingir ordens mais elevadas de intencionalidade, tomando como referência a tese da complexidade do ambiente social e a hipótese da inteligência social. Explora-se as implicações dessas teses para a questão de como evoluiu, no gênero Homo, uma modalidade de aprendizagem social que possibilitou a acumulação cultural. A partir desse pano de fundo, expõe-se como Richerson e Boyd explicam a evolução da ultrassociabilidade humana pressupondo uma interação entre herança cultural e herança genética e traça-se um paralelo com a história natural que nos oferece Tomasello das origens da cultura humana e do papel que desempenha na coordenação social. A segunda parte do artigo é uma tentativa de explicitar, nesses e em outros cenários, algumas imagens de natureza humana que são pressupostas tacitamente. Para tanto, discute-se vários temas: a ambivalência entre conflito e cooperação no tratamento da evolução humana; a sempre renovada controvérsia entre adaptacionistas e construtivistas; e a possibilidade de um vínculo mais estreito entre os processos de desenvolvimento e de evolução. Ao final são esboçadas algumas idéias, com um caráter programático, sobre como essas imagens se articulam com outras: relativas à linguagem, como traço distintivo da nossa espécie, e à arquitetura da mente humana.

Palavras-chave: cultura e evolução humana; evolução da cooperação; teoria da dupla herança; intencionalidade coletiva; imagens de natureza humana

\footnotetext{
${ }^{*}$ Professor titular aposentado do Departamento de Filosofia da Universidade de Brasília (UnB). E-mail: abrantes@unb.br
} 
Abstract: This paper deals with the role culture plays in different scenarios for human evolution. The first part presents the basic elements of an explanation for the capacity of the human mind to reach higher orders of intentionality, taking on board the thesis of the complexity of the social environment and the social intelligence hypothesis. The implications of those thesis for the question of how evolved, in the Homo genus, a modality of social learning that made possible cultural accumulation are explored. Given this background, the way Richerson e Boyd explain the evolution of human ultrasociality, pressuposing an interaction between cultural inheritance and genetic inheritance, is exposed, and comparisons are made with how Tomasello depicts the origins of human culture and the role it plays in social coordination in his natural history. The second part of the paper attempts to make explicit in those scenarios and others some images of human nature that are tacitly presupposed. To accomplish this, various themata are adressed: the ambivalence between conflict and cooperation in dealing with human evolution; the controversy between adaptationists and constructivists, which is still going on; the possibility of a tighter link between developmental and evolutionary processes. At the end, some tentative and programatic ideas are deployed, concerning how those images are articulated with others: related to language, as a distinctive trait of our species, and to the architecture of the human mind.

Keywords: culture and human evolution; evolution of cooperation; dual inheritance theory; culture and colective intentionality; images of human nature.

Neste artigo pretendo discutir a tese de que o mundo da cultura é o mundo por excelência de uma espécie particular, o Homo sapiens, e que várias características dessa espécie, em particular as psicológicas, evoluíram nesse mundo.

Essa investigação passa necessariamente pela questão de qual tipo de mente é capaz de assimilar e transmitir cultura com a eficiência que humanos o fazem. Em um sen- etimologia do termo ${ }^{1}$ ). É preciso,

\footnotetext{
${ }^{1}$ Um animal tem anima, que é a tradução usual para psyché, do grego. A referência ao De Anima de Aristóteles é inescapável neste contexto. O grande filósofo grego distingue quatro tipos de alma: nutritiva, locomotora, sensitiva e intelectiva. O homem seria o único animal a tê-las todas.
} 
contudo, identificar o que é específico à mente humana e como isso engendrou uma dinâmica cultural que, por sua vez, distanciou progressivamente as mentes dos nossos ancestrais hominínios das mentes de animais em outras linhagens, como a linhagem que se bifurcou na dos chimpanzés (Pan troglodytes) e dos bonobos (Pan paniscus), com a qual a linhagem hominínia compartilhou um ancestral comum há aproximadamente 7 Maa. $^{2}$

Os cenários que apresentarei a seguir são especulativos, pois tratam de eventos que ocorreram há centenas de milhares de anos, de que não temos evidências empíricas diretas (processos mentais e comportamentos não deixam fósseis!). As evidências indiretas que dispomos são insuficientes para excluir cenários alternativos. Tanto mais importante é a tarefa filosófica de explicitar e confrotar as imagens de natureza humana que estão implicadas em cada um destes. $^{3}$

\section{A complexidade do ambiente so- cial}

A tese da complexidade ambiental (Godfrey-Smith, 1998) dispõe que mentes de diferentes tipos evoluíram para lidar com a variabilidade e imprevisibilidade do meio ambiente, seja no espaço, seja no tempo. Quanto mais variável e imprevisível, mais complexo é o ambiente para um dado sistema cognitivo (ou mente).

Ambientes com certos graus de complexidade, nesse sentido do termo, exerceram pressão seletiva que favoreceu a evolução de tipos de mentes capazes de plasticidade comportamental, como é o caso dos sistemas intencionais (Abrantes, 2006). Esses sistemas são capazes de representar o mundo externo e, além disso, as suas representações estão dissociadas de um comportamento particular, podendo ser exploradas, portanto, de modo "promíscuo"(Hurley, 2003, p.1). Isto significa que os conteúdos de certos estados mentais podem ser apropriados por vários outros, de diferentes tipos, em situações as mais diversas. O comportamento desses sistemas cognitivos torna-se, assim, mais flexível e menos automático, aumentando a sua aptidão (sucesso reprodutivo) em lidar com a complexidade dos ambientes físico, biológico e, sobretudo, social.

$\mathrm{O}$ meio ambiente social humano

\footnotetext{
${ }^{2}$ Maa = milhão de anos atrás.

3 Para a noção de 'imagem' ver Abrantes, 2016. Não pretendo aqui me debruçar sobre os aspectos propriamente epistemológicos (as imagens de ciência) que participam dessa empreitada, o que fiz em outros lugares (Abrantes, 2011c, 2012). Remeto às considerações de Perez, neste volume, que aborda esses aspectos.
} 
é muito complexo dada a imprevisibilidade do comportamento dos indivíduos que o integram (afinal, são sistemas intencionais!), o que pode ter gerado uma corrida armamentista (arms race) que resultou em mentes capazes de ordens mais elevadas de intencionalidade e dotadas de uma genuína inteligência social (Humphrey, 1988). Essa "inteligência" está associada a mentes capazes de interpretar o comportamento de outros indivíduos, atribuindo-lhes estados mentais de diferentes tipos (emoções, crenças, desejos, intenções, etc.). ${ }^{4}$

Uma explicação para essa escalada metarrepresentacional seria a seguinte: sistemas intencionais têm um comportamento mais plástico comparados a tipos mais simples de sistemas cognitivos. Um ambiente social no qual existem tais agentes é, portanto, mais complexo, o que gera pressões para que evoluam capacidades de "leitura de mentes" (mind reading). ${ }^{5}$ Tomar outros indivíduos do seu grupo social como agentes e atribuirlhes estados mentais para explicar e prever o seu comportamento é também uma condição para poder manipular as suas mentes e, portanto, para enganar, dissimular etc., daí se falar de uma "inteligência maquiavélica". ${ }^{6}$ A necessidade de melhor detectar desertores e egoístas teria sido a pressão seletiva mais importante na evolução da capacidade humana para a leitura de mentes (Byrne \& Whiten, 1988).

Uma mente capaz de ordens elevadas de intencionalidade muito provavelmente é específica do sapiens, e é preciso tratar das pressões seletivas que expliquem, de modo detalhado e plausível, a evolução ascendente das capacidades metarepresentacionais (Sperber, 2000). Dunbar (2000) estabeleceu uma correlação entre tamanho relativo do neocórtex e tamanho dos grupos sociais em várias linhagens,

\footnotetext{
${ }^{4}$ A intencionalidade de primeira ordem corresponde à capacidade para representar aspectos de um mundo real ou imaginário. Trata-se de 'intencionalidade' no sentido de Brentano. Intencionalidades superiores à de primeira ordem correspondem a capacidades metarrepresentacionais. A representação de uma representação apresenta uma intencionalidade de segunda ordem. O estado mental 'crer que fulana não deseja que sicrano saiba que irão a uma festa hoje' apresenta uma intencionalidade de terceira ordem, etc.

${ }^{5}$ Essa explicação evolucionista pressupõe a chamada 'hipótese da inteligência social' evocada acima. Há quem a rejeite e defenda, em vez disso, que os hábitos de interpretação têm uma ontogenia mas não uma filogenia (Suddendorf, 2011, p. 121-24). Em outros termos, essa explicação alternativa propõe que as habilidades para lidar com o meio social são aprendidas ao longo do desenvolvimento dos indivíduos, normalmente com a ajuda de outros indivíduos experientes, sobretudo dos pais. Pode-se combinar processos ontogenéticos e filogenéticos, o que me parece uma perspectiva promissora para se compreender a origem de uma inteligência social que suponha mind reading. Trato dessa possibilidade adiante. Por outro lado, é também defensável que a inteligência social, em muitas espécies, apóie-se exclusivamente numa leitura fina do comportamento de outros indivíduos (behavior reading), o que tem custos menores, em termos de processamento cognitivo, do que a leitura de mentes.

${ }^{6}$ A idéia de inteligência social é mais abrangente pois contempla não somente um ambiente no qual as relações são conflituosas (requerendo uma inteligência propriamente "maquiavélica") mas também um ambiente em que predominem interações cooperativas entre os indivíduos de um grupo. Ver Hurford, 2014, p. 48.
} 
que serviu de base para a sua "hipótese do cérebro social". 7 A capacidade para atingir ordens cada vez mais elevadas de intencionalidade acompanharia, segundo essa hipótese, o aumento na complexidade do ambiente social medida por esse parâmetro (Gamble et al. 2014, p. 146).

\section{Leitura de mentes e a psicologia de senso comum}

Outras espécies animais, sobretudo os grandes símios- cujas linhagens compartilham ancestrais comuns recentes com a linhagem hominínia-, vivem em ambientes sociais bastante complexos, hierarquizados, onde imperam conflitos, muitas vezes envolvendo coalizões (Boehm, 1999). Quais os requisitos cognitivos para se navegar com sucesso nesses ambientes? Uma resposta comum a essa questão referese a uma capacidade para a 'teoria da mente' (ToM), expressão que se cristalizou a partir de pesquisas em primatologia para aferir se chimpanzés, os nossos primos filogeneticamente mais próximos, possuem tal capacidade. ${ }^{8}$ Houve várias mudanças no posicionamento dos especialistas a esse respeito. De toda forma, a capacidade para a leitura de mentes no gênero Homo seguramente deita raízes em capacidades menos sofisticadas para a ToM. ${ }^{9}$

A leitura de mentes pode servirse de um esquema conceitual como o da psicologia de senso comum (PS). O fato é que usamos a PS não somente para descrever o que se

\footnotetext{
7 Da-Glória, neste volume, elenca esta entre outras explicações para a encefalização. No contexto do presente artigo, não vejo diferença relevante entre a hipótese de Dunbar e a hipótese da inteligência social mencionada anteriormente, a menos que se queira tomar partido com respeito ao problema mente-cérebro e defender que isso tem implicações para as discussões em pauta.

8 A expressão 'teoria da mente', bastante equívoca, aparece pela primeira vez na literatura, ao meu conhecimento, num artigo publicado em 1978 por Premack e Woodruff. Essa expressão induz o leitor, equivocadamente, a supor um procedimento particular - o de aplicar uma teoria - para a atribuição de estados mentais a outros (supostos) agentes (Abrantes, 2014a). Não há, contudo, um compromisso dessa expressão com este ou qualquer outro mecanismo particular para fazer tais atribuições (e há vários propostos na literatura; Diana Perez os elenca neste volume). É comum também se usar, para se referir a essa capacidade, a expressão 'leitura de mentes' (mind reading), que se distingue de uma simples capacidade para 'ler comportamentos' (behavior reading), distinção que fiz na nota 5. Uma outra possibilidade seria designar a leitura de mentes como envolvendo estados mentais com uma intencionalidade de segunda ordem ou, ainda, como uma capacidade para a metarrepresentação. Dennett, por sua vez, refere-se a ela como a capacidade para interpretar, no caso, comportamentos.

${ }^{9}$ Podemos distinguir, por exemplo, a capacidade para 'ler' estados mentais com conteúdo (e.g. crenças) e a capacidade para sentir empatia, ler emoções de um outro indivíduo como dor, medo, pesar, etc. Há evidências de que babuínos (macacos do velho mundo do gênero Papio com os quais compartilhamos um ancestral comum há 30 Maa) são sensíveis às intenções e motivações de um outro indivíduo, possivelmente por leitura de comportamento, mas não são capazes de sentir empatia, o que requer a atribuição de estados mentais (Cheney \& Seyfarth, 2007, p. $159,191-8)$. Essa condição certamente mudou nos milhões de anos seguintes de evolução dos ancestrais comuns que compartilhamos com os grandes símios, mas as evidências a respeito da capacidade destes últimos para atribuir estados mentais de diferentes tipos são de difícil interpretação. O título do livro de Cheney \& Seyfarth é uma alusão sugestiva à frase que Darwin escreveu no seu Notebook M em 1838, dois anos após ter retornado da viagem no Beagle, quando estava trabalhando intensamente no desenvolvimento da sua teoria (Abrantes, 2016): "Origin of man now proved._Metaphysic must flourish._He who understands baboon would do more towards metaphysics than Locke".
} 
passa em nossas mentes mas também para imputar estados mentais, sempre conjecturalmente é claro, a outros seres humanos. ${ }^{10} \mathrm{Na}$ verdade, fazemos isso de forma tão automática e compulsiva que não restringimos tais imputações a seres da nossa espécie (vistos, nessa medida, como agentes), mas também a outros animais (sobretudo os de nossa estimação!); aqueles ainda mais liberais, o fazem mesmo com respeito a objetos inanimados, incluindo os artefatos que construímos! ${ }^{11}$

Pode-se questionar em que medida a psicologia de senso comum (PS) é um bom instrumento conceitual para descrever mentes. Para Dennett (1998), a PS seria, propriamente, uma arte [craft] cuja função precípua é a interpretação do comportamento humano em nosso cotidiano e não a descrição da mente, uma tarefa de outra ordem, científica (Godfrey-Smith, 2003, p. 267). Os eliminativistas defendem, por sua vez, a proeminência das descrições neurofisiológicas. Mesmo que mostrem ter razão no futuro, acredito que a PS continuará cumprindo bem o seu papel na interpretação do comportamento dos nossos coespecíficos no meio social e, portanto, é virtualmente ineliminável dada sua relativa simplicidade e poder preditor.

O artigo de Diana Perez neste volume me dispensa de tratar dos pressupostos metafilosóficos do meu posicionamento a favor da relevância da PS; tampouco precisarei entrar em detalhes a respeito da discussão sobre os mecanismos subjacentes à leitura de mentes. ${ }^{12}$ Posso concentrar-me aqui em discorrer sobre a nossa capacidade para galgar ordens elevadas de intencionalidade, o que possibilitou a criação de um mundo cultural e, por um processo complexo de coevolução, deu origem a uma "mente embebida na cultura".

Mesmo que aceitemos o eliminativismo com respeito à PS enquanto um marco psicológicoconceitual para descrever mentes, ainda assim os nossos hábi-

\footnotetext{
${ }^{10}$ A PS pode ser usada de dois modos distintos (Abrantes, 2011a): (i) como um esquema conceitual para descrever mentes (como tendo, grosso modo, uma arquitetura crença-desejo); (ii) para dar suporte à interpretação, explicação e previsão do comportamento de outros (supostos) agentes, imputando-lhes estados mentais.

$11 \mathrm{O}$ animismo e o panpsiquismo são manifestações dessa aplicação da PS fora do seu âmbito apropriado, em que outros animais, e mesmo objetos físicos, são também considerados agentes. Com a Revolução Científica do séc. XVII houve uma gradativa contenção desse uso indiscriminado, en outrance (Descola, 2005, p. 33-5), da PS: só coespecíficos são tomados como agentes. Surge uma tendência a se separar as esferas do mental, da vida, e do físico, uma história com muitas reviravoltas (Abrantes, 2016). Essa separação justifica-se, já que o mundo físico é menos complexo do que o mundo social. Portanto, é desnecessário, excessivo, usar a "postura intencional" para explicar sistemas físicos, quando podemos usar a "postura de projeto" ou a "postura física" (Dennett, 1991, 1995). Agentes no meio social, pela natureza opaca do seu comportamento (Abrantes, 2006), exigem um sistema mais poderoso de previsão e de explicação: a leitura de mentes.

12 Tratei desses temas em outros artigos: Abrantes (2010, 2011a, 2013b).
} 
tos de interpretação, nessas bases, podem ter desempenhado um papel importante na evolução do tipo humano de mente (mesmo que esta possa ser mais adequadamente descrita por meio de uma ciência cognitiva futura que não tenha qualquer dívida com a PS).

Defendo portanto, ao lado de outros pesquisadores, que a leitura de mentes é parte relevante da explicação de como teria evoluído a mente do sapiens, e não se limita a ajudar cada um de nós na navegação social ordinária. ${ }^{13}$ Quando surgiram mentes capazes de ler outras mentes surgiu uma nova pressão seletiva no sentido de que evoluíssem mentes mais sofisticadas, configurando a corrida armamentista a que me referi anteriormente. ${ }^{14}$

\section{A cultura como um novo sistema de herança}

Há dezenas de definições de cultura e a opção por uma delas depende dos objetivos perseguidos por um programa de pesquisa (Abrantes, 2014b). Se em- prestarmos à biologia o conceito de 'fenótipo' - como o conjunto de traços (ou características) apresentados pelo indivíduo (organismo ou agente)-, podemos em certos casos incluir no fenótipo os traços culturais ao lado de outros tipos de traços: anatômicos, fisiológicos, etc. O que é distintivo de um traço cultural (como, por exemplo, o de usar instrumentos líticos como os machados de mão, falar uma determinada língua ou adotar uma religião) é o fato de que em sua ontogenia a aprendizagem social faz-se presente. ${ }^{15}$ Há diversas modalidades de aprendizagem social (Abrantes \& Almeida, 2011, p. 263) mas aqui me interessa sobremaneira a imitação fidedigna, que é condição necessária para que a cultura possa ser herdada e acumulada.

Um grau moderado de variabilidade no ambiente físico pode ter favorecido a evolução da aprendizagem social, já que esta possibilita uma economia dos custos e riscos associados à aprendiza-

\footnotetext{
13 Ver, em especial, Godfrey-Smith (2002, 2003, 2004, 2005).

${ }^{14}$ Há também toda uma literatura sobre o desenvolvimento das capacidades para a ToM. Com base no chamado 'teste de falsa crença', sabemos que antes de 3 ou 4 anos crianças não são capazes de atribuir a outros indivíduos estados mentais com conteúdo, como crenças (ver Perez, neste volume). Muito se escreve ainda sobre como essas evidências sobre a ontogenia da ToM em humanos relacionam-se com hipóteses sobre a sua filogenia (por exemplo, Mithen, 2002). A relação entre o autismo e deficiências relacionadas à capacidade para a leitura de mentes é também muito estudada (Suddendorf, 2013, p. 168).

15 Pode-se defender que há traços culturais de grupos, como adotar uma certa forma de organização política, ou um sistema jurídico. Estou me restringindo, nessas linhas, ao caso mais ortodoxo de que somente indivíduos têm fenótipos culturais. Ver, porém, a discussão mais adiante sobre seleção no nível de grupo.

16 Comportamentos inatos são favorecidos por ambientes muito estáveis. A aprendizagem individual é favorecida, no extremo oposto, por ambientes muito instáveis. Modelos matemáticos mostram que em condições intermediárias de variabilidade ambiental a aprendizagem social por imitação é a melhor estratégia adaptativa. Para
} 
gem individual. ${ }^{16}$ Ao que tudo indica, a evolução da imitação fidedigna como modalidade específica de aprendizagem social requer, além disso, pressões seletivas associadas ao ambiente social. ${ }^{17}$

É importante distinguir a posse de cultura da sua acumulação. Para que a cultura se acumule é preciso que os traços culturais sejam transmitidos de indivíduo para indivíduo, e de geração para geração, de modo fidedigno. Caso contrário, cada indivíduo teria que servir-se de outra modalidade de aprendizagem social e/ou aprender por si só, individualmente, como parece ser o caso em outras espécies. ${ }^{18}$

Um produto da acumulação cultural como o computador, que estou usando para escrever este texto, contou com a inventividade de vários indivíduos num esforço que se prolongou por várias gerações e em diferentes áreas (matemática, computação, eletrônica, etc.). Nenhum indivíduo, por mais brilhante que fosse, teria sido capaz de inventar sozinho esse artefato, mesmo que tivesse tido tempo disponível para tanto ao longo da sua existência. ${ }^{19}$

A cultura pode funcionar como um sistema de herança somente se há algum mecanismo que dê apoio ao que Tomasello chamou de "efeito catraca"(1999, 2014). A capacidade para a aprendizagem social por imitação (ou aprendizagem observacional) pode desempenhar esse papel. Muitos investigadores defendem que a capacidade para imputar estados mentais a outros - em particular, a de atribuir uma intenção ao outro quando se comporta de determinado modo - é um requisito para que se possa imi-

\footnotetext{
detalhes a respeito, ver Abrantes \& Almeida, 2011; Abrantes, 2011c; Neco \& Richerson, 2014. Ver também DaGlória, neste volume. Laland (2017, p. 189-191) contesta esse cenário e aposta na estabilidade criada por nichos construídos, o que configura uma imagem que contrasta com o adaptacionismo do cenário anterior, como discutirei adiante.

17 Richerson \& Boyd mostraram, com base em modelagem matemática, que há uma barreira (um vale adaptativo) à evolução da imitação fidedigna pois esta tem um custo, contrariamente ao que se pode pensar, pois requer uma capacidade psicológica especial para a leitura de mentes. Essa capacidade psicológica pode ter evoluído originalmente para lidar com a complexidade do ambiente social (o que configura uma aplicação da hipótese da inteligência social, já mencionada). Esse vale adaptativo teria sido transposto no gênero Homo por esta vantagem adaptativa conferida pela leitura de mentes. Em seguida, como um efeito secundário, essa capacidade psicológica pode ter sido recrutada para a aprendizagem observacional possibilitando, a partir daí, a acumulação cultural (Richerson \& Boyd, 2005, 100, 138-9; Abrantes \& Almeida, 2011, p. 264-270; Mithen, 2005, p. 311 nota 31; cf. Laland, 2017, p. 130, 150). Teríamos, no caso, uma exaptação da ToM, o que implicaria que não evoluiu para possibilitar a acumulação cultural. Sobre a diferença entre exaptação e adaptação, ver Sepúlveda et al., 2011.

18 Encontramos cultura em várias espécies, desde que o termo 'cultura' seja definido de modo adequado, mas a acumulação cultural, ao que tudo indica, só ocorre de modo significativo em nossa espécie. Embora esta seja uma posição muito debatida (Martínez-Contreras, 2011; Abrantes, 2014b, p. 16; Hodgson \& Knudsen, 2010, p. 159), continua sendo defendida na literatura e respaldada por pesquisas recentes sobre comportamento animal (Laland, 2017 , p. $4-11,97-8,154)$.

19 Talvez caiba falar, nesse contexto, de 'evolução cultural' (tecnológica, no caso em tela), em um sentido análogo ao de 'evolução biológica' (Abrantes, no prelo; cf. Laland, 2017, p. 166).
} 
tar fidedignamente seu comportamento (Blackmore, 2000; cf. Laland, 2017, p. 187). Esta modalidade de aprendizagem social teria evoluído somente no gênero Homo. $^{20}$

Os articuladores da teoria da dupla herança (TDH), como o nome indica, defendem que a cultura tornou-se um sistema de herança a partir de um certo ponto da linhagem hominínia, quando passou a atuar em paralelo com o sistema genético de herança, que está na base de toda forma de vida. ${ }^{21}$

\section{Uma história da psicologia social humana}

A interação entre os sistemas de herança genético e cultural produziu efeitos com enormes consequências para a evolução humana. Talvez o mais importante diga respeito ao comportamento cooperativo em grandes grupos, envolvendo indivíduos não aparentados.

Uma das peculiaridades da teoria da TDH é o modo como incorpora a cultura na evolução de um equipamento psicológico que possibilitou a cooperação em larga escala. A ênfase que essa teoria dá à herança cultural coloca em pauta, de um lado, diferentes tipos de aprendizagem, como discuti acima e, de outro, a psicologia social subjacente à ultrassociabilidade humana.

No que diz respeito à aprendizagem, vimos que a capacidade para imitar de modo fidedigno estaria, possivelmente, assentada na ToM. Passou-se, também, a imitar não de modo indiscriminado, mas enviesado. Vieses como o conformista uma tendência a imitar o comportamento mais frequente no grupo e a seguir modelos - uma tendência a se imitar, preferencialmente, indivíduos que ocupam uma posição

\footnotetext{
${ }^{20}$ Mesmo que se reconheça que outras espécies sejam capazes de imitar, há consenso que humanos o fazem numa gama de situações e com uma fidelidade que não encontra paralelo em outros animais. Crianças imitam ações de uma outra pessoa mesmo quando não são as mais eficientes para se atingir um objetivo, ou mesmo são supérfluas, fenômeno conhecido como "superimitação" (Suddendorf, 2013, p. 168)! Chimpanzés não se deixam desviar pelo que faz o demonstrador e escolhem os meios que julgam atingir mais diretamente o objetivo. Ver Krupenye et al. (2016) e Dean et al. (2012) para resultados experimentais recentes a esse respeito.

${ }^{21}$ Rosana Tidon, neste volume, desenvolve este ponto e menciona outros pesquisadores que estão trabalhando numa versão estendida da teoria da evolução que admite a existência de outros sistemas de herança além do genético.

22 A fidelidade e a estabilidade da transmissão cultural podem estar garantidas no nível da população (herdabilidade cultural) mesmo que falhem entre indivíduos. A construção de nichos também garante essa herdabilidade. No que diz respeito às pressões seletivas responsáveis pela evolução dos vieses psicológicos na transmissão cultural, cada um deles requer um tratamento especial. É bastante intuitivo que o conformismo pode ser uma boa estratégia em situações nas quais o indivíduo não consegue decidir sozinho a respeito do comportamento mais adaptativo. Modelos matemáticos construídos por vários autores vão ao encontro dessa intuição, mostrando que o viés conformista evolui por seleção natural nas mesmas condições ambientais em que a aprendizagem social é favorecida, como abordei na nota 16 (Richerson \& Boyd, 2005, p. 122; Richerson \& Boyd, 2013; Henrich \& Boyd, 1998; Abrantes \& Almeida, 2011, p. 293, nota 30; Neco \& Richerson, 2014; Hodgson \& Knudsen, 2010, p. 140,
} 
destacada no grupo-, potencializaram a transmissão cultural de uma geração para outra. ${ }^{22}$

Além dos vieses na aprendizagem social que acabo de mencionar, teriam evoluído, segundo a $\mathrm{TDH}$, outros traços psicológicos, incluindo propensões a seguir normas e a punir egoístas e desertores. A sanção moral é uma condição necessária, mas não suficiente, para a evolução da cooperação: um estoque de emoções, como a culpa e a vergonha, evoluiu de modo a aumentar o custo da deserção e tornar desnecessária a sanção na maioria dos casos. Richerson e Boyd incluem essas propensões e emoções no que denominam "instintos tribais". ${ }^{23}$ Estes diminuem o custo em seguir normas de cooperação e aumentam, concomitantemente, o custo da deserção. Como consequência, há um nivelamento na aptidão dos indivíduos dentro do grupo, diminuindo a força da seleção no nível do indivíduo relativamente à força da seleção no nível do grupo. ${ }^{24}$
Inclui-se ainda nessa psicologia social uma sensibilidade aguçada a marcadores simbólicos, que consolidam a identidade cultural de cada grupo ao erguerem barreiras à migração entre eles (a linguagem sendo especialmente eficaz nesse tocante). ${ }^{25}$

\section{Alguns marcos cronológicos}

É muito arriscado fazer qualquer indicação a respeito de quando a cultura começou a se acumular no gênero Homo, a funcionar como um novo sistema de herança e a interagir com o sistema genético de herança.

Há evidente estase na indústria Olduvaiense (2 a 1,5 Maa) - possivelmente associada ao $H$. habilis embora várias espécies hominínias vivessem à mesma época na África e são também candidatas. Um outro longuíssimo período de inércia observa-se nos registros arqueológicos da indústria que se segue, a Acheulense (1,7 a 0,25 Maa), associada inequivocamente ao H. ergas-

\footnotetext{
159-161). Entretanto, há também que se levar em conta a relevância das pressões seletivas do ambiente social para que se possa vencer a barreira adaptativa para a evolução da imitação, como mencionei na nota 17. Temos aqui uma combinação complexa de pressões dos ambientes físico e social. Laland enfatiza o papel do ensino na acumulação cultural além daquele, mais óbvio e não desvinculado do anterior, da linguagem (2017, p. 157-58; 174). Mas isso só desloca a questão para outras, igualmente complexas, ligadas à evolução do ensino e à evolução da linguagem, como discuto ao final deste artigo.

23 Segundo a TDH, a evolução tratou de assimilar geneticamente comportamentos, diminuindo o custo envolvido no cálculo da estratégia mais adaptativa, além de reduzir o custo do erro na aprendizagem individual em certas condições ambientais. Alguns traços psicológicos humanos seriam inatos, no sentido de fortemente canalizados pelos genes. Ao mesmo tempo, convém ressaltar que o meio ambiente sempre joga um papel na manifestação dos traços fenotípicos sobretudo, mas não exclusivamente, naqueles que são comportamentais, o que é consensual entre os defensores das várias abordagens aqui examinadas que tomam a biologia como marco teórico.

24 Richerson et al., 2003, p. 368; cf. Richerson et al., 2002.

25 Para detalhes, ver Abrantes \& Almeida, 2011.
} 
ter. ${ }^{26}$ Esta foi a primeira espécie do gênero a sair da África, e continuou evoluindo na Ásia para o Homo erectus (1,9 a 0,2 Maa). Esta última, embora tenha sido a espécie de maior sucesso evolutivo do gênero Homo já que foi a mais longeva, manteve-se produzindo ferramentas mais simples, semelhantes às da indústria Olduvaiense, por todo esse imenso período.

A estase cultural pode estar ligada a limitações cognitivas. Uma outra hipótese, que me parece mais plausível, é que essa inércia deu-se por uma demografia muito baixa. Se os grupos que produziram os artefatos dessas indústrias eram muito pequenos, a simples deriva cultural pode ter impedido a acumulação de cultura. Explico-me: inovações podem ter surgido (e.g. novas técnicas de fabricação de artefatos líticos) mas não terem sido transmitidas de um indivíduo para outro, ou de geração a geração, devido a contingências ligadas à fissão dos grupos de hominínios em resposta às condições ecológicas que prevaleciam à época (ver Grove et al., 2012; Foley et al. 2001, 2009, 2011). Pode-se vislumbrar uma combinação dessas duas hipóteses (cognitiva e demográfica), acrescida de outras, para explicar a estase cultural nessas espécies do gênero Homo. ${ }^{27}$ Laland defende, com base em experimentação com aprendizes contemporâneos, que a estase da cultura de Olduvai foi devida a uma transmissão deficiente de habilidades com base exclusivamente na imitação e na emulação, sem ensino ou algum meio de comunicação eficaz na forma de uma proto-linguagem, por exemplo (2007, p. 204).

A estase Acheulense termina há 0,25 Maa, início do Paleolítico médio, e passamos a ter uma mudança cultural sustentada, com maior diversidade de artefatos e diferenças regionais entre os vários grupos de hominínios, o que sugere uma resposta à questão de quando a cultura passa a funcionar como um sistema de herança (Rosenberg, 2006 p. 215). A hipótese da deriva, que defendi acima, sugere, contudo, que as evidências arqueológicas podem não refletir os processos relevantes: o equipamento psicológico necessário para que a cultura se acumule ao longo das gerações pode ter evoluído muito antes disso, mas a deriva ter impedido

\footnotetext{
${ }^{26}$ A datação é aproximativa e vem sendo modificada constantemente em função de novas descobertas. Há quem distinga, como faço aqui, os fósseis de H. ergaster encontrados na África dos fósseis de H. erectus encontrados na Ásia apesar das suas similaridades, mas não há consenso entre os especialistas. Da-Glória, neste volume, menciona uma única espécie, o erectus, e não faz essa distinção filogenética e geográfica.

27 Os efeitos da deriva cultural em função de mudanças demográficas foram bem documentados em populações que viviam na Tasmânia há milhares de anos antes de lá chegarem exploradores europeus no séc. XIX (Henrich, 2004; Richerson \& Boyd, 2005, p. 138).
} 
que esse potencial se manifestasse no registro arqueológico. Efetivamente, há $500 \mathrm{mil}$ anos houve um grande surto no crescimento do cérebro, o que pode indicar que já se tivesse atingido ordens mais elevadas de intencionalidade associadas a uma leitura sofisticada de mentes, possibilitando a imitação fidedigna. $\mathrm{O}$ ator em cena era o $H$. heidelbergensis $(\sim 700$ a $200 \mathrm{mil}$ aa) que foi o ancestral comum do $H$. neanderthalensis ( $\sim 400$ a $40 \mathrm{mil}$ aa) e do H. sapiens. A nossa espécie teria surgido há, pelo menos, 200 mil aa, pelas evidências atualmente disponíveis. ${ }^{28}$ Uma outra hipótese, compatível com a anterior, é que esse pico na encefalização tenha estado associado a pressões seletivas para uma melhor comunicação através de uma protolinguagem, mesmo que somente gestual (Mithen, 2005, p. 159).

Laland defende uma posição menos restritiva do que a minha e recua a acumulação cultural para o início da cultura Acheuliense, a despeito da longa estase que se seguiu. Ele considera que a primeira saída da África pelo ergaster, que já teria caçado de modo sistemático e usado o fogo, são evidências suficientes de que uma dinâmica já estivesse ocorrendo no campo cultural. $^{29}$

\section{Cooperadores desde o início?}

Um cenário que propõe Tomasello complementa, a meu ver, aquele oferecido pela TDH e o enriquece, sobretudo no que diz respeito à evolução da psicologia humana e sobre como está cravada no mundo cultural. A cultura sempre desempenhou um papel central nesse cenário que vem traçando para o desenvolvimento e a evolução humanas desde, pelo menos, o seu livro de 1999, mas ele próprio reconhece que em seu livro mais recente, de 2014, implementa mudanças significativas no pano de fundo. A ênfase não é mais colocada na cultura como um "processo de transmissão" mas como um "processo de coordenação social" (Tomasello, 2014, p. x).

A "história natural" que ele nos oferece coloca o foco, sobremaneira, na psicologia subjacente à "coordenação social" (Tomasello, 2014, p. 4). Essa história te-

\footnotetext{
28 A datação para o surgimento do $H$. sapiens tem sido cada vez mais recuada e não me espantaria se alguma evidência nova mostrar, de modo cabal, que a nossa espécie esteve perambulando pela África há mais tempo que isso. Há também muito debate sobre a quantidade de espécies do gênero Homo e seu relacionamento taxonômico; mudanças na sua nomenclatura e na filogenia têm sido frequentes para acomodar as novas evidências, sobretudo as que afluem em enorme quantidade da genética.

29 Laland $(2017$, p. 10, 185-89, 200, 204-5). Hurford (2014, p. 5, 15, 82, 91) sugere uma posição mais próxima à que defendo. Da-Glória, neste volume, apresenta evidências do uso de símbolos, provavelmente com função social, em espécies hominínias vivendo há 500 mil anos, o que reforça a minha hipótese, mais conservadora do que a de Laland.
} 
ria se desenrolado em três etapas, correspondendo a diferentes formas de intencionalidade: individual (individual intentionality), conjunta (joint intentionality) e coletiva (collective intentionality). ${ }^{30} \mathrm{~A}$ cada uma dessas adaptações está associada uma modalidade específica de pensamento, envolvendo representação, inferência e automonitoramento.

Os grandes símios já seriam capazes, segundo Tomasello, de intencionalidade individual. A cognição associada possui várias das propriedades do que chamei anteriormente um 'sistema intencional' (embora Tomasello não use essa denominação), em especial a de possibilitar grande flexibilidade comportamental na lida com os ambientes físico e social, quando comparada a sistemas cognitivos mais simples (Abrantes, 2006). Efetivamente, o grande símio tem que ser capaz de representar suas experiências e seus objetivos com um certo grau de abstração; fazer simulações com essas representações em contextos distintos daquele que se apresenta em dado momento; e transformar essas representações usando vários tipos de inferências. Ele também precisa monitorar suas representações, os objetivos que se coloca e como afetam seu comportamento. Tais cognições são muito sofisticadas, mas Tomasello defende que os grandes símios têm mentes desse tipo, o que permite que pensem a dinâmica do mundo físico- com a imprevisibilidade que apresentava sobretudo no Plioceno e no Pleistoceno-, e especialmente do mundo social. Ele chega a afirmar que esses símios não somente são agentes intencionais como percebem os seus congêneres como também o sendo. Suas mentes funcionam de modo eficiente em contextos sociais marcados pela competição (Tomasello, 2014, p. 20; 2008, p. 177).

Mudanças no ambiente criaram as condições para que evoluíssem comportamentos cooperativos simples, que pressupõem uma capacidade para a intencionalidade conjunta. Eles foram precursores da cooperação ampla que se verificou posteriormente em grupos de hominínios. O indivíduo passa a ser motivado a desenvolver atividades com um outro indivíduo, e é capaz de representar a perspec-

\footnotetext{
30 Quero frisar que essa noção de intencionalidade não é a mesma usada anteriormente no presente artigo, que remete a Brentano, como indiquei na nota 4. Trata-se, em Tomasello, de 'intenção' no sentido de uma meta, de colocar-se um objetivo, de fazer algo tendo em vista um fim, seja individualmente seja com outros indivíduos. Entretanto, embora não mencione Brentano, a noção de intencionalidade deste último está implícita nas várias modalidades de pensamento que discute Tomasello, que envolvem a capacidade para representar e para leitura de mentes, como discutirei a seguir. Ver também a nota 33.
} 
tiva distinta deste último, embora ambos persigam, supostamente, o mesmo objetivo (a intenção conjunta de, por exemplo, carregar uma tora de madeira, o que cada um deles não conseguiria fazer isoladamente). Essa interdependência requer atenção conjunta e coordenação entre os indivíduos, que frequentemente assumem papéis diferentes na atividade (Tomasello, 2008, p. 170).

A intencionalidade conjunta pressupõe também automonitoramento da conduta em função de como os outros a avaliam, o que constituiu um embrião de sensibilidade às normas sociais, que se afirmará na etapa seguinte de uma genuína intencionalidade coletiva. Aquele tipo de intencionalidade está associado à comunicação gestual, pré-linguística, como na pantomima. Os gestos, além de terem uma semântica, podem ser combinados numa sintaxe que anteciparia a de uma linguagem convencional.

Além de automonitoramento é preciso simular a perspectiva do outro visando o sucesso da operação conjunta como, por exemplo, ao apontar para algo que um indivíduo considere seja informação relevante para o outro, dirigindo sua atenção para um objetivo que supõe também persiga.

Para Tomasello, a etapa intermediária da intencionalidade conjunta é importante pois evita um salto da intencionalidade individual para a coletiva, o que contrariaria o gradualismo tão prezado por um tratamento evolutivodarwinista. A próxima etapa nessa história evolutiva conjectural ${ }^{31}$ é, portanto, a de uma intencionalidade coletiva, caracterizada por um pensamento "objetivo-reflexivonormativo", visando a coordenação social (Tomasello, ibid., p. 4).

Esse pensamento é "objetivo" porque consegue trabalhar com diferentes perspectivas, supostamente as de outros agentes que lidam conjuntamente com um mesmo problema que importa a todos. $^{32}$

Supõe-se, além disso, uma capacidade para fazer leitura de mentes com uma estrutura recursiva, em que se concatena os estados mentais atribuídos a outros agentes com os do próprio agente: 'eu espero que ele saiba que eu não pretendo ajudá-lo a fazer isso, mas que estou disposto a fazer aquilo que ele também quer fazer'. ${ }^{33} \mathrm{O}$ agente faz então inferências com base nas relações que estabelece

\footnotetext{
31 Tomasello assume plenamente o caráter especulativo da sua proposta (2014, p. 152).

32 Tomasello (2014, p. 120) associa essa objetividade, significativamente, à view from nowhere de T. Nagel.

33 Essa recursividade compreende as diversas ordens de intencionalidade (no sentido de Brentano) a que fiz menção no início deste artigo.
} 
entre o que ocorre consigo e aquilo que simula das intenções e crenças dos outros agentes ("inferências recursivas sociais”).

Esse pensamento próprio do $s a-$ piens é, além disso, "normativo" porque o agente consegue avaliar e regular o seu comportamento, e os estados mentais que o afetam, levando em consideração as regras de conduta e convenções do grupo a que pertence. Trata-se de uma "coletivização" das capacidades associadas à intencionalidade conjunta, descritas anteriormente (Tomasello, ibid. p. 93).

A evolução do pensamento e da comunicação, desde o nosso ancestral comum com os chimpanzés até o surgimento do gênero Homo (em torno de 2Maa), deu-se por mudanças ecológicas que exigiram cooperação, o que implicou, por sua vez, "novas formas de comunicação cooperativa"(Tomasello, 2014, p. 36).

A principal pressão ecológica nos primórdios do gênero Homo, que teria desencadeado aquela evolução, consistiu na proliferação dos macacos terrestres, que passaram a competir com nossos ancestrais por frutas e vegetais diversos. Eles foram forçados, então, a ocupar novos nichos ecológicos, inicialmente como carniceiros (meat scavengers), o que requeria capacidade para a intencionalidade conjunta e, posteriormente, para a in- tencionalidade coletiva.

Tomasello defende que o Homo heidelbergensis já exercia a intencionalidade conjunta há $400 \mathrm{mil}$ anos (Tomasello, ibid. p. 36, 141). Ele caçava animais grandes com armas, o que exigia trabalho $\mathrm{co}^{-}$ ordenado. Eu também ofereci argumentos acima que sugerem que, a essa altura, já se era capaz de acumular cultura (e consequentemente que esta passara a funcionar como uma nova modalidade de herança).

\section{A cultura no cenário de Tomasello}

Esse psicólogo admite que outras espécies, em especial os grande símios, são capazes de aprendizagem social e têm, portanto, cultura (que compreende comportamentos típicos de um grupo que se mantêm por muitas gerações). Mas Tomasello a distingue da "cultura humana" (Ibid., p. 82). Esta última promove a colaboração, enquanto que a cultura dos grandes símios é eminentemente "exploradora" (exploitive). A etapa da intencionalidade comum, de práticas de cooperação envolvendo duplas de indivíduos foi, segundo Tomasello, uma pré-condição para que se passasse da aprendizagem social, que já ocorria no ancestral comum da nossa linhagem e a dos chimpanzés, para uma "aprendizagem cultural", que ele entende 
como a tradução mesma da cooperação que se dava nos primeiros grupos de sapiens (ibid., p. 82, 128). Ele defende que certas modalidades de coordenação entre indivíduos na linhagem hominínia precederam, evolutivamente, o papel que a cultura passou a desempenhar nesses grupos (Tomasello, 2009, p. 93-5).

A cultura passou a ser a "base comum" convencional de normas, instituições e linguagem, um "mundo público" em que se apóia uma cooperação mais ampla e que fornece identidade ao grupo $(2014,5,85,115$ ). Tomasello introduz essa cultura propriamente humana em sua história natural quando os grupos crescem e, num ambiente de conflito com outros grupos, tornam-se uma grande unidade cooperativa guiada por uma "mente de grupo" (group-mindedness). Percebe-se, claramente, uma convergência entre o cenário esboçado por Tomasello nessa etapa e aquele da $\mathrm{TDH}$, a despeito das diferenças de terminologia. O viés conformista desta última é traduzida, em Tomasello, pelo que denomina "normas de conformidade" (2009, p. 93-5). Há que se reconhecer, contudo, que estas normas têm uma objetividade para o grupo, enquanto os vieses da TDH são psicológicos (embora compatilhados por todos os indivíduos e, portanto, universais). fundo comum é, de toda forma, que a competição entre grupos exige que cada um tenha homogeneidade interna e seja bem delimitado por seus respectivos traços culturais, que funcionam como marcadores simbólicos.

Ressaltei que em Tomasello a cooperação nas atividades de forrageamento (tanto na caça quanto na coleta) na fase inicial da evolução no gênero Homo, alicerçadas na intencionalidade conjunta, antecedeu a emergência de uma forma de cultura especificamente humana. Aquela fase preliminar está ausente do cenário da TDH. Os proponentes desta teoria tendem a ver a cooperação ampla entre os membros do grupo como consequência da acumulação cultural, que só ocorre significativamente a partir de um certo ponto da evolução no gênero Homo, como discuti antes. Mas a cooperação já deveria ocorrer muito antes, em menor escala: embora seja admissível que se possa aprender observando o comportamento de alguém que seja um egoísta, certamente essa aprendizagem é muito mais efetiva se o outro indivíduo colaborar de alguma forma com aquele que quer imitá-lo, e desse modo a cultura se acumularia com mais facilidade. Não vejo incompatibilidade entre os dois cenários mas uma diferença de ênfase: ToO masello coloca em evidência que a 
cooperação estava presente desde o início, embora restrita a poucos indivíduos. Pode-se inferir que ele dá mais importância do que Richerson e Boyd a pressões seletivas ocorrendo no nível do indivíduo, como fator relevante na evolução da cooperação. Volto a isso mais a frente.

Por outro lado, Tomasello também atribui um papel significativo ao conflito entre grupos na evolução de um novo conjunto de capacidades cognitivas e de uma nova modalidade de comunicação, sobretudo em períodos mais recentes da evolução humana. ${ }^{34}$ A seleção no nível do grupo teve, portanto, um papel central nesse processo em ambos cenários. Para tanto, fatores demográficos (maiores populações) e o conflito entre grupos foram responsáveis pelas pressões que levaram a que o sapiens galgasse a terceira etapa na sua evolução cognitiva: a de uma intencionalidade coletiva.

\section{Conflito e cooperação}

Enquanto filósofo, interessome pelas imagens de natureza humana assumidas, por vezes tacitamente, pelos pesquisadores que construíram esses diferentes ce- nários. Chama a minha atenção, nesse tocante, a ambivalência entre conflito e cooperação no modo como os biólogos, antropólogos e psicólogos evolutivos abordam a evolução do comportamento humano, o que sugere que diferentes imagens estão implícitas nas suas apostas explicativas. ${ }^{35}$ Vou explicitar nesta e nas seções seguintes alguns desses pressupostos, de caráter mais filosófico, que se encontram em camadas mais profundas, menos visíveis, dos vários cenários aqui investigados.

A despeito da grande atenção que, desde cedo, Darwin concedeu ao altruísmo (que estaria por trás da existência das castas neutras nos insetos sociais, por exemplo), ele considerou indispensável a luta pela existência (struggle for life) para que se dê o processo de seleção natural. ${ }^{36}$ Por isso, mantevese associada ao darwinismo a imagem de uma natureza "vermelha em dentes e garras"(red in tooth and claw).

Haveria como superar essa ambivalência ou ela é inerente ao processo de seleção natural e, portanto, a qualquer abordagem biológica do comportamento? $\mathrm{O}$ altruísmo e, de modo mais geral, o comportamento cooperativo é efe-

\footnotetext{
34 Tomasello 2014, p. 93, 121; 2009, p. 86-7, 93-5; 2009, p. 99; 2008, p. 213-14.

35 As imagens de ciência subjacentes não estão sendo tratadas aqui, como deixei claro na nota 3.

36 Entretanto, as formulações recentes da seleção natural tendem a ser mais abstratas e não explicitam essa condição (Godfrey-Smith, 2009, p. 17-20).
} 
tivamente difícil de ser compreendido num quadro de referência evolutivo. Para tanto, Darwin sugeriu que a seleção atue também no nível da "família" (Darwin, 2003, p. 243). Ao debruçar-se sobre o caso humano na sua obra de 1871, ele apela para a moral que, ao promover comportamentos prósociais, dá ao grupo mais chances de sobreviver e crescer na competição com outros grupos que tenham menos indivíduos altruístas:

Não pode ser esquecido que, embora um alto padrão de moralidade confira pouca ou nenhuma vantagem para cada homem individualmente ou para suas crianças em relação aos outros membros da tribo, um acréscimo no número de pessoas capacitadas e um avanço no padrão de moralidade certamente dará impensa vantagem a uma tribo em relação a outra. Uma tribo que tivesse muitos membros que, possuindo em alto grau o espírito do patriotismo, da fidelidade e da obediência, coragem e simpatia, estivessem sempre prontos para ajudarse mutuamente e sacrificarse pelo bem comum, seria vitoriosa sobre a maioria das outras tribos; e isso seria a seleção natural (Darwin,

$$
\text { 2004, p. 157-8). }
$$

Podemos identificar aí uma imagem de natureza que supõe que os comportamentos pró-sociais geram um benefício para o grupo, mesmo que diminuam a aptidão dos indivíduos no interior do grupo. O apelo ao "bem do grupo", de modo a explicar o altruísmo em termos biológicos, tornou-se comum desde a proposta original de Darwin, mas passou a ser duramente criticado por alguns biólogos muito influentes na segunda metade do séc. XX, o que fez praticamente desaparecer essa imagem. Ela foi substituída por uma na qual a seleção só pode atuar em níveis inferiores ao do grupo: seja o do indivíduo, seja o do gene (Bernal \& Abrantes, no prelo). A partir de então, os biólogos evolucionistas tenderam a enfatizar as propensões humanas para o conflito, que compartilharíamos com outros animais. A idéia de uma inteligência maquiavélica pressupõe, claramente, um cenário de conflito entre os indivíduos, como assinalei antes.

Surpreendentemente, observouse nos últimos anos uma tendência oposta: a cooperação passou a ser tomada como modelo para explicar as diversas transições em individualidade que ocorreram desde o surgimento da vida na Terra, a exemplo da emergência dos organismos 
multicelulares que pressupõe a colaboração e a divisão de trabalho entre as suas células (Queller, 1997; Abrantes, 2013a, 2014c). A própria célula eucariota pode ser descrita como envolvendo a colaboração entre organelas que, antes, viviam autonomamente.

Entretanto, essa tendência a privilegiar a cooperação não elimina o conflito, simplesmente o desloca para um outro nível da hierarquia biológica. Por exemplo, no caso da transição para os organismos multicelulares, o conflito deixa, em larga medida, de ocorrer entre as células para se dar entre os próprios organismos. No caso humano, vimos exemplos disso nos cenários propostos por Richerson, Boyd e Tomasello: a seleção natural atua em pelo menos dois níveis simultaneamente: do indivíduo e do grupo. ${ }^{37}$

No contexto da discussão sobre como diferentes imagens de natureza humana influenciaram o modo de se pensar o comportamento pró-social em termos evolutivos, é importante ressaltar que muitos dos defensores da relevância da seleção de grupo percebem a sua proposta como estando em oposição a uma perspectiva individualista que campeia em mui- tas áreas da biologia e das ciências sociais (nestas últimas, esta posição é mais comumente conhecida como 'individualismo metodológico'). Nas discussões sobre os fundamentos da biologia essa perspectiva é conhecida como 'funcionalismo individual', que se contrapõe ao 'funcionalismo de grupo'. Nesta última posição, grupos são considerados reais de um ponto de vista ontológico e não simplesmente um mero somatório de indivíduos (Sober \& Wilson, 2003, p. 10-11, 159; Wilson \& Sober, 1994; Hodgson \& Knudsen, p. 155, 164).

\section{Evolução do igualitarismo}

A cooperação esteve associada a uma estrutura social mais igualitária em grupos de hominínios do Pleistoceno, que também nesse tocante se distanciaram gradualmente das estruturas hierárquicas típicas dos grandes símios onde um ou poucos indivíduos monopolizam os recursos, sejam estes alimentos ou parceiros sexuais. Várias pressões seletivas, tanto do ambiente físico quanto do social e cultural, combinaram-se para produzir essa evolução (Plazas \& Rosas, 2014). Quero destacar somente uma delas, que está mais

\footnotetext{
37 Os mecanismos selecionistas clássicos adotados para explicar o altruísmo tendem a selecionar egoístas. Mesmo a seleção de parentesco e o altruísmo recíproco podem ser considerados mecanismos que pressupõem uma natureza egoísta (a preservação dos meus genes em gerações futuras), e somente explicam a cooperação em grupos de indivíduos aparentados geneticamente. Ver Bernal \& Abrantes, no prelo.
} 
diretamente ligada aos temas que abordo neste artigo: a formação de coalizões envolvendo um grande número de indivíduos.

Chimpanzés formam coalizões para se confrontarem ao macho alfa, mas poucos indivíduos as integram, pois a formação de coalizões maiores é muito exigente do ponto de vista psicológico. Em contraste, Boehm $(1999,2006)$ defende que se instalou em grupos de hominínios uma "hierarquia invertida" em que o líder do grupo passa a ser submetido aos ditames da maioria dos seus membros, o que criou as condições para a evolução de uma genuína "psicologia igualitária”. Não me parece espúrio vincular esta tese de Boehm às de Tomasello acerca da evolução da intencionalidade coletiva, bem como às teses da TDH sobre as funções do viés conformista e dos instintos tribais, desde que se tenha presente que esses traços psicológicos provavelmente evoluíram em diferentes momentos. Todos eles aumentam a intensidade da seleção que atua no nível do grupo, comparada à que atua em níveis inferiores.

$\mathrm{O}$ arremesso de pedras e outros objetos por coalizões- mesmo sem o uso de dispositivos com esse fim, o que só se deu em períodos mais recentes-, certamente contribuiu para dissuadir os grandalhões dominadores, reduzindo a sua aptidão em comparação com os indivíduos mais fracos e/ou menos agressivos. A partir de um certo momento, essas pressões igualitárias passaram a ser consubstanciadas em normas aceitas pelo grupo, que cuidava para que fossem seguidas fazendo, eventualmente, uso de sanções morais mais ou menos severas. ${ }^{38}$

Podemos até especular que esses grupos igualitários tenham passado a funcionar, em várias situações, como verdadeiros indivíduos, no sentido biológico do termo (Abrantes, 2013a). Tomasello defende uma versão psicológica dessa tese: os grupos igualitários passaram a ter uma "mente de grupo" (a ser "group minded"), o que exigia "objetividade" da parte de cada agente no tocante às normas e aos interesses do seu grupo como um todo, ofuscando em grande medida a sua perspectiva e os seus próprios interesses enquanto indivíduo (2014, p. 92-3, 153).

Com a chegada do Holoceno há 12 mil anos instalou-se um

\footnotetext{
38 Cabe aqui uma referência às "normas de conformidade" de que nos fala Tomasello e que abordei acima. Não tenho espaço para tratar aqui do tema correlato da evolução da moralidade, que certamente infletiu a trajetória da evolução humana numa nova direção, como já sugerira Darwin. Isso vem sendo abordado pela incorporação mais efetiva de conceitos emprestados à biologia contemporânea. Ver a esse respeito Rex \& Abrantes, 2017; Almeida \& Abrantes, 2012.
} 
clima estável e o contexto da evolução humana mudou completamente. A invenção da agricultura possibilitou a vida sedentária e grande crescimento populacional, exigindo formas mais complexas de organização social, não mais baseadas no igualitarismo mas na hierarquia e centralização do poder. O conflito entre grupos nômades e sedentários provavelmente se acirrou, já que nestes últimos os recursos se concentram espacialmente (Abrantes, 2014c).

A dinâmica cultural acelerou-se enormemente e tornou-se o fator principal. A partir daí temos, como preferem alguns, História, no sentido mais usual do termo. Embora a evolução biológica não tenha deixado de ocorrer, o seu passo é muitíssimo mais lento que o da dinâmica cultural. Além disso, transcorreu desde então um intervalo de tempo muito curto para que a evolução com base na herança genética pudesse afetar significativamente traços complexos, como os psicológicos e comportamentais. A evolução biológica já não mais respondeu pelas mudanças vertiginosas que conduziram ao espectro comportamental observado nas sociedades atuais. Outros instrumentos conceituais, desenvolvidos pe- las ciências sociais, têm que ser acionados para compreendermos a saga humana recente. ${ }^{39}$

As mudanças nesses últimos milhares de anos se apoiaram, entretanto, no equipamento psicológico que havia evoluído no Plioceno e no Pleistoceno, num espaço de tempo de, pelo menos, 2 milhões de anos (se nos ativermos ao que ocorreu a partir do surgimento do gênero Homo). Elementos característicos da cultura humana, como a religião e a própria ciência, por exemplo, teriam sido possibilitados por recrutaram diversas dessas capacidades, como a de ler mentes e cooperar em grandes grupos (Norenzayan et al. 2013; Slingerland et al., 2013).

\section{Adaptacionismo e construtivismo}

O adaptacionismo é uma tese a respeito do poder da seleção natural: a maioria dos traços dos organismos, sobretudo aqueles que são complexos, deve ser explicada pelo processo de seleção natural à exclusão de outros como, por exemplo, a deriva (Sober, 2000, p. 124).

$\mathrm{O}$ adaptacionista comete o erro, acusam os seus críticos, de pressupor que todas as características dos organismos são adaptações ótimas ao ambiente em que vivem (o que

\footnotetext{
${ }^{39}$ Isso não impede que se tente aplicar modelos importados da biologia evolutiva para se pensar a evolução cultural, como indiquei na nota 19, e mesmo para explicar eventos em períodos muito recentes da história humana. Ver, a esse respeito, Almeida (2016).
} 
Gould chamou, ironicamente, de "paradigma panglossiano") e que possuiriam, por conseguinte, uma função (por isso essa posição é também conhecida como 'funcionalista'). Nem todas as características dos organismos são, na verdade, adaptações, desempenham funções e tampouco são ótimas (Sepúlveda et al., 2011).

As críticas de Gould e Lewontin ao adaptacionismo, em seu influente artigo de 1978, podem ser consideradas construtivistas em seu caráter: os seres vivos não são passivos, defendem eles, mas alteram o seu ambiente de modo fundamental, modulando dessa forma as pressões seletivas. $\mathrm{O}$ construtivismo volta a colocar o organismo no centro do processo: em vez da visão de um nicho a priori (ao invocar a metáfora, bastante comum, da chave-fechadura) haveria uma interação dinâmica entre os organismos e seus ambientes. O adaptacionista, como interpretado usualmente, não leva em conta a construção de nichos como força evolutiva.

No entanto, outros fatores são (igualmente) relevantes na evolução além da seleção natural: contingências históricas (que podem ser responsáveis pela deriva, por exemplo), restrições biológicas (formas pre-existentes que são cooptadas para outros fins), a canalização no desenvolvimento devido a tais restrições, etc.

Um dos alvos das críticas de Lewontin e Gould foram as estorietas (just-so stories) adaptacionistas, propostas para explicar toda sorte de característica dos organismos, tanto relativas à forma quanto à função. A tese adaptacionista a respeito do poder explicativo da seleção natural (à exclusão de outros mecanismos) não seria testável; e as estorietas geradas nessas bases tampouco poderiam ser submetidas à prova empírica (Sober, 2000, p. 124).

Qual a incidência dessa controvérsia em filosofia da biologia para a temática deste artigo?

Traços psicológicos e comportamentais são, seguramente, complexos e o adaptacionista defende que evoluíram por seleção natural e não poderiam ser explicados por outros processos. A própria cultura é considerada uma adaptação (Richerson \& Boyd, 2005, cap. 4), bem como a ultrassociabilidade humana.

Em oposição a isso, o construtivista enfatizará que humanos são construtores de nicho por excelência e a cultura é uma componente central desses nichos. A espécie humana evoluiu pelas pressões seletivas exercidas também pelo nicho cultural (pode-se dizer, alternativamente, que o sapiens ocupou esse nicho). Odling-Smee e colaboradores $(2003$, p. 14,245$)$ defen- 
dem que ao lado de uma herança genética e de uma herança cultural existe também uma "herança ecológica", que lega às gerações futuras os ambientes construídos pelas que as antecederam (Abrantes \& Almeida, 2011, p. 287-90). Os indivíduos humanos se desenvolvem nesses nichos construídos e grande parte das suas características psicológicas e comportamentais (que são o foco deste artigo) expressamse na ontogênese. Cada geração participa, de modo crucial, da formação das novas gerações, preparando o ambiente para que ela se dê de forma adequada a um ambiente particular, social e cultural (o que pode ser visto como um tipo de canalização, por analogia com a canalização genética).

Nesse contexto, o ensino adquire um significado especial. Em outras espécies, incluindo os grandes símios, ele é raríssimo. Grupos humanos, por sua vez, envolveramse não somente com o ensino (enskillment) de habilidades complexas demais para serem aprendidas por adultos inexperientes mas, sobretudo, com o ensino de crianças, de modo a criar um ambiente propício ao seu desenvolvimento (Laland,
2017, p. 167-68, 188).

O fato de que os bebês nascem cada vez mais prematuros- devido a mudanças anatômicas na pelve em consequência da postura ereta e ao concomitante crescimento do cérebro-, se comparados aos recém-nascidos de outras espécies, requer mais cuidado parental e por mais tempo permitindo, por sua vez, um período mais longo de aprendizagem social. Isso abriu espaço para uma diversidade de trajetórias ontogenéticas e maior flexibilidade comportamental (Perez, neste volume; Mithen, 2005).

O cuidado parental destaca-se na evolução da cooperação no gênero Homo, já que avós e adultos de outras famílias passam a cuidar das crianças, liberando as mães para a atividade de coleta de alimentos, que são repartidos na coletividade. ${ }^{40}$ Essas redes de colaboração (ao lado da caça cooperativa envolvendo, sobretudo, homens) podem ter estado na base de unidades de cooperação mais amplas dentro do grupo (Tomasello, 2014, p. 133; 2009, p. 83-6). Este psicólogo, indo ao encontro de outros cientistas e filósofos construtivistas, não considera as "adaptações bio-

\footnotetext{
40 A longevidade das mulheres após a menopausa é um enigma de uma perspectiva evolucionista. Se o cuidado dos netos aumentar as chances de que estes sobrevivam, esse enigma se dissolve com base na aptidão inclusiva (os genes que são compartilhados entre avós e netos têm maior probabilidade de se propagar). O cuidado coletivo com as crianças, mesmo por parte daqueles que não são familiares, pode ser explicado por aumentar a disponibilidade de alimentos para o grupo como um todo (caso as mães e os pais, liberados para a caça e a coleta, se dispuserem a compartilhá-los, é claro), além de contribuir para a transmissão da cultura do grupo para esses novatos. Ver Suddendorf, 2011, p. 228-9.
} 
lógicas" associadas à intencionalidade coletiva como "simplesmente inatas", mas entende que emergem ao longo do desenvolvimento num ambiente preparado com esse fim. Aprendizes (tipicamente crianças) desenvolvem as habilidades para objetividade, reflexividade e normatividade nas suas interações com outros indivíduos experientes do seu grupo, em meio a uma cultura acumulada por várias gerações, com seu conjunto de normas, convenções e instituições. A comunicação através da linguagem simbólica seria também imprescindível para maior efetividade da intencionalidade coletiva (2014, p. 146-8).

Se nos afastarmos do adaptacionismo e do funcionalismo que estão implícitos tanto na abordagem que aponta para a seleção no nível mais baixo possível (o do gene) quanto na que prega que a seleção atua em múltiplos níveiso que leva a se buscar adaptações/funções em cada um delesindo em vez disso na direção do construtivismo-, abrem-se as portas para outras explicações possíveis dos comportamentos cooperativos, sobretudo no caso humano. Ao sugerir acima uma maior aproximação entre desenvolvimento e evolução, já estava sinalizando esse novo caminho.

Há propostas para se explicar a ultrassociabilidade humana diminuindo a centralidade que tem a seleção de grupo na TDH e dando mais ênfase aos processos ontogenéticos e de construção (cultural) de nicho. A cooperação no forrageamento, com divisão de trabalho entre mulheres e homens, bem como o cuidado parental compartilhado podem ter aumentado a aptidão dos indivíduos desde muito cedo no gênero Homo. ${ }^{41}$

As novas gerações herdam nichos construídos e se beneficiam do envolvimento ativo das gerações mais velhas no ensino das competências relevantes para se viver neles. O compartilhamento de informações importantes para a sobrevivência, o envolvimento em estratégias coletivas de defesa contra predadores na savana, a construção coletiva de abrigos também se incluem nessas práticas cooperativas.

Certas motivações e características emocionais, como maior tolerância com respeito aos aprendizes, especialmente crianças e jovens, devem ter emergido nesse processo envolvendo múltiplos fatores num entrelaçamento com-

\footnotetext{
${ }^{41}$ Indiquei acima que Tomasello, em contraste com os articuladores da teoria da dupla herança, inclina-se mais para essa posição. O adaptacionista pode replicar levantando a possibilidade de ter havido seleção sexual por parte das mulheres, que escolhiam homens mais dispostos a colaborar na criação das crianças e na sua alimentação. Isso teria contribuído, inclusive, para uma diminuição do dimorfismo sexual (Plazas \& Rosas, 2014, p. 282-84).
} 
plexo entre evolução e desenvolvimento.

Essa ênfase nas pressões seletivas que atuam sobre o indivíduo pode ser interpretada como um retorno ao individualismo metodológico, mas a centralidade da construção de nichos na história natural que nos contam indica que se trata de uma posição que se localiza entre os extremos do individualismo e do 'coletivismo'- se me permitem o termo para não cair no cipoal semântico de outros como 'holismo'. ${ }^{42}$

Também pode-se pressupor que no clima extremamente adverso do Pleistoceno os grupos frequentemente precisavam cooperar entre eles, pois as dificuldades momentâneas de um deles seriam mitigadas pela ajuda de um outro que estivesse em melhor situação naquele momento; e, claro, essa situação sempre podia inverter-se e gerava a expectativa de reciprocidade (Sterelny, 2012).

\section{Desenvolvimento e evolução}

A visão construtivista favorece, portanto, uma aproximação entre desenvolvimento (ontogenia) e evolução (filogenia), abordagem conhecida como 'evo-devo' ou 'biologia evolutiva do desenvolvi- mento', que tem mobilizado muitos esforços atualmente, tanto de biólogos quanto de filósofos (ver Bloise \& Folguera, neste volume). Antropólogos como Ingold também entraram em cena, radicalizando essa visão: 'genes' e 'cultura' existiriam somente nos "olhos dos investigadores": o processo real seria o de um "vir a ser biossocial" em um "campo de relações" (Ingold, 2013, p. 12; Ingold, 2000, p. 385 ; Fuentes, 2013, p. 48). O construtivismo de Ingold revela-se em sua defesa da posição, já exposta acima, de que o desenvolvimento de um indivíduo desde a sua infância acontece em um ambiente que é preparado pelas gerações anteriores (Ingold, 2001, p. 139; 2013; Fuentes, 2013, 2016).

Para a teoria dos sistemas de desenvolvimento (Griffths \& Gray, 1988) a evolução é a replicação diferencial de ciclos de um processo de desenvolvimento e não, simplesmente, a reprodução diferencial de organismos- vistos como expressões fenotípicas de genótipos, como na teoria evolutiva que resultou da grande síntese com a genética. A proposta é não separar o organismo do ambiente (físico, biológico, social e, nos casos pertinentes, cultural) e tampouco privilegiar algum recurso do sis-

\footnotetext{
42 Sterelny defende, entretanto, que o conflito entre grupos e a seleção de grupo passam a ser inescapáveis para explicar o que ocorre no Holoceno, como detalho em Abrantes, 2014c, p. 299-301.
} 
tema como, por exemplo, o gene (Oyama, 1966, 2000; cf. Bloise \& Folguera, neste volume). $\mathrm{Na}$ linha dos defensores da teoria dos sistemas de desenvolvimento, Ingold (1994, p. 8) argumenta que as capacidades atribuídas aos indivíduos são, na verdade, propriedades dos sistemas de desenvolvimento, contrapondo-se aos que pressupõem, por exemplo, a existência de uma capacidade humana para a cultura com uma base genética, como é o caso dos proponentes da TDH.

Especialmente no caso humano, genes e culturas participam dos processos integrados de desenvolvimento e evolução, gerando características espécie-específicas, inclusive no plano psicológico. As estruturas sociais, por exemplo, enquanto "elementos da cultura", são requeridas para a "replicação estável de características psicológicas humanas evoluídas" (Griffiths \& Gray, 1998, p. 141; cf. Laland, 2017 , p. 190,194$)$.

Uma implicação dessa abordagem é que a história passa a ser vista como uma continuação da evolução (Ingold, 2013, p. 9). Oyama, indo nessa direção, vislumbra um contínuo entre a história evolutiva (filogenia), a história dos historiadores e a história de desenvolvimento de um indivíduo (ontogenia). Teríamos, na sua visão, uma única histó- ria biológica dos humanos, englobando todas essas histórias parciais (Oyama, 1996, p. 357). Evidentemente, a biologia a que se refere não é somente a evolutiva mas inclui também a biologia do desenvolvimento e, provavelmente, outras áreas da biologia e de ciências afins (ver Bloise \& Folguera, neste volume).

\section{Linguagem e evolução humana}

Abri este artigo defendendo a importância de se identificar a especificidade da mente humana e de explicá-la. É comum invocar-se imediatamente a linguagem- com as características com que hoje se apresenta (caráter simbólico e convencional, sintaxe, recursividade, generatividade, composicionalidade, etc.), em comparação com as formas de comunicação que observamos em outras espécies-, como sendo o grande divisor de águas na evolução humana. A imagem de que a linguagem é o traço distintivo da espécie humana deita raízes não somente no senso comum mas também numa tradição filosófica e científica que remonta, pelo menos, a Descartes (lembremos que para ele o fato dos animais não passarem no teste da linguagem provaria que não pensam).

O tema da evolução da linguagem é extremamente complexo e suscita muita controvérsia- eu não 
poderia sequer dar aqui os primeiros passos para abordá-lo cabalmente. ${ }^{43}$ Gostaria somente de marcar posição a respeito de um ponto: embora seja indubitável que a forma humana de se comunicar através da linguagem não tem paralelo em outras espécies, é um equívoco colocá-la cedo demais em cena na trajetória evolutiva da mente humana. Além de não oferecer uma explicação aceitável da singularidade dessa trajetória, essa atitude impede que o próprio tema da evolução dessa modalidade de comunicação, com seus pré-requisitos psicológicos, anatômicos etc., seja abordado (Tomasello, 2008, p. 59).

Sem dúvida, a partir do momento em que humanos tiveram linguagem com as propriedades acima elencadas, isso impulsionou enormemente a dinâmica cultural; mas não podemos nos furtar a tratar dos períodos iniciais dessa evolução nos quais, segundo os registros arqueológicos disponíveis, a cultura mudava mais lentamente ou mesmo apresentava estase, como ressaltei anteriormente. No entanto, esses primevos acontecimentos podem ter sido cruciais para se compreender como surgiu a própria linguagem! Por exemplo, muitos pesquisadores defendem, de modo convincente, que a comunicação através da linguagem pressupõe a capacidade para leitura de mentes e precisaríamos, em primeiro lugar, explicar a emergência desta última e de capacidades relacionadas, como tentei sucintamente nas seções anteriores. ${ }^{44}$

Outra questão: a modalidade de inteligência requerida para lidar com a complexidade dos ambientes sociais pressupõe a linguagem ou evoluiu de forma independente? Há vários cenários que podem ser explorados. Em um deles, a ToM seria um requisito tanto para uma inteligência social quanto para o exercício de uma forma de comunicação sofisticada (supondo-se que aumentam a aptidão dos indivíduos nesses ambientes). Pode-se vislumbrar, também, cenários de coevolução entre essas capacidades.

Tomasello argumenta que novas modalidades de cooperação estavam associadas a novas formas de comunicação: primeiramente havia a "comunicação colaborativa" pré-linguística através de gestos naturais e pantomima; mais tarde, evoluiu uma linguagem convenci-

\footnotetext{
43 Ver Pievani, 2014; Saraiva, 2014; Hurford, 2014; Tomasello, 2008. Da-Glória, neste volume, oferece evidências anatômicas e genéticas relevantes para balisar a evolução da linguagem.

44 Seyfarth \& Cheney, 2013, p. 68-70; Malle, 2002; Tomasello, 2014, p. 127; Sperber, 2000, p. 121; Dennett, 1995 , p. 378-380. Para a relação entre leitura e comunicação linguística no desenvolvimento infantil, ver Tomasello, 2000, p. $110-103,174-182$.
} 
onal a partir daquela forma de comunicação (2008, p. 219-20).

O cenário de Mithen para a evolução da linguagem, a que faz referência Diana Perez neste volume, centra-se nas implicações evolutivas da postura ereta, que fez com que os hominínios nascessem cada vez mais cedo, alargando o período de cuidado parental e, portanto, de maior interação entre as crianças e seus genitores. A postura ereta não somente teve implicações para a rigidez e posicionamento da laringe como teria aumentado a necessidade de maior controle sensório-motor; esse cérebro mais complexo pode ser exaptado para outras funções ligadas à socialização, à musicalidade e formas mais sofisticadas de comunicação prélinguística (Mithen, 2005, p. 14658).

A linguagem verbal com as características atuais é, muito provavelmente, um produto relativamente recente da evolução do $H$. sapiens. Pode até ser que se tenham passado dezenas de milhares de anos desde o surgimento desta espécie para que a linguagem tivesse adquirido característi- cas como recursividade, por exemplo. A explosão cultural do Paleolítico superior, há somente $50 \mathrm{mil}$ anos atrás, pode ser um indicador de que a evolução da linguagem tivesse atingido um novo patamar, embora o processo tenha, provavelmente, sido gradual e começado muito antes. ${ }^{45}$

Portanto, não devemos apelar para a linguagem cedo demais para explicar a trajetória particular, e extraordinária, que a evolução tomou no gênero Homo. A acumulação cultural é uma melhor candidata para explicar a origem dos nossos traços espécie-específicos e não precisava, em suas etapas iniciais, de uma linguagem como a nossa atual para que pudesse ocorrer. Inverter essa ordem causal seria "colocar o carro na frente dos bois", um dito popular para um erro igualmente popular. ${ }^{46}$

Cenários com um caráter mais construtivista também podem ser explorados. Laland defende, por exemplo, que a acumulação cultural e o ensino geraram as pressões seletivas para o surgimento de uma linguagem cada vez mais sofisticada. Por sua vez, a lin-

\footnotetext{
45 Para McBrearty e Brooks, num artigo que teve grande impacto, o "equipamento cognitivo" que possibilitou esse esplendor cultural já estava presente há, pelo menos, 250 mil anos, ou seja, antes mesmo do surgimento da nossa espécie. Fatores de várias ordens, inclusive demográficos, impediram que a cultura tivesse se manifestado antes de modo tão magnífico, ao menos com base nas evidências que dispomos hoje (2000, p. 458, 531-2). Vimos que Mithen, em oposição a isso, defende a tese do desencapsulamento da mente humana para explicar o que foi, para ele, uma mudança abrupta na evolução do sapiens. Em um livro mais recente, continua defendendo essa posição no que diz respeito à evolução da linguagem (Mithen, 2005, p. 257-259). Cf. Rosenberg, 2006, p. 220.

46 Cf. Dediu et al. 2013; Hurford, 2014, p. 39.
} 
guagem, por retroalimentação, aumentou a fidelidade na transmissão de cultura, acelerou a sua dinâmica, melhorou a eficiência do ensino e diminuiu os seus custos. Teríamos uma coevolução complexa entre esses processos e as capacidades cognitivas que lhes dão suporte, incluindo a teoria da mente (Laland, 2017, p. 167-68; 184, 19497).

Laland vê, portanto, a evolução de formas mais sofisticadas de comunicação como tributárias da necessidade de se transmitir, através do ensino, formas culturais complexas que resultaram de acumulação ao longo de gerações. Inicialmente, crianças eram ensinadas desse modo no âmbito familiar e depois indivíduos em um círculo cada vez mais amplo dentro do grupo cultural (2017, p. 185192). Nesse cenário, foi a acumulação cultural que exerceu a pressão seletiva crucial para que o ensino evoluísse; este último, por sua vez, exigiu uma forma de comunicação mais eficiente e acurada através da linguagem.

\section{Imagens de mente}

Para concluir, vou tratar de forma rápida de um outro conjunto de imagens que, por si só, exigiriam artigos exclusivamente dedicados a elas. Mas como são incontornáveis, pois associadas de várias maneiras às imagens discutidas até aqui, correrei uma vez mais o risco de simplificar brutalmente.

Cenários para a evolução humana pressupõem imagens de mente. Os psicólogos evolucionistas, por exemplo, rejeitam a imagem de uma mente que resolve problemas os mais diversos com um dispositivo genérico (imagem que atribuem às ciências sociais) e a substituem pela imagem de uma mente dividida em módulos, cada um especializado numa tarefa relevante no ambiente ancestral em que, supostamente, evoluiu o sapiens (Waizbort \& Porto, 2011). Tanto Sperber quanto Mithen adotam, com modificações menores, essa imagem. O primeiro defende, inclusive, a existência de um módulo para a metarrepresentação e Mithen o acompanha nesse tocante (2002, p. 309). Como vimos, este último supõe que, em certo momento, os módulos mentais que eram inicialmente encapsulados passaram a trocar informação dando margem a uma grande fluidez cognitiva. Ele usa essa hipótese, como vimos, para explicar a explosão cultural que ocorreu no Paleolítico superior (Ibid., p. 249), e que nos rendeu as fabulosas pinturas rupestres de Chauvet e Lascaux, para ficarmos com as realizações desses sapiens (Cro-Magnons) que mais nos impressionam. Tenho reservas a respeito dessa ima- 
gem modular de mente e faço as minhas críticas em outro lugar. ${ }^{47}$

Richerson e Boyd evitam, cautelosamente, ingressar nessa seara mais filosófica, embora simpatizem com alguns aspectos do modularismo da psicologia evolucionista proposta pela escola de Sta. Bárbara. Eles não podem, contudo, admitir uma implicação dessa imagem de mente: de que a cultura é informação contida nos vários módulos mentais e meramente evocada pelo ambiente e não transmitida de indivíduo para indivíduo. Aceitar isso seria colocar por terra o pilar central da TDH: de que a cultura funciona como um sistema de herança (2005, p. 5; 44-5)! Indubitavelmente, é muito menor o papel que desempenha a cultura na evolução humana segundo o cenário daquela versão da psicologia evolucionista. ${ }^{48}$

Gostaria de apontar simplesmente, já que não há espaço aqui para desenvolver essa tese, que uma abordagem construtivista da evolução de uma "mente embebida na cultura", que dê ao desenvolvimento um papel crucial nesse processo, pode reforçar a imagem de uma mente corporificada (embo- died), situada e estendida (no sentido de envolver o ambiente em seu funcionamento cognitivo). ${ }^{49}$

$\mathrm{Na}$ concepção de uma mente estendida, a cultura e nichos construídos desempenham papéis centrais não só na economia cognitiva de um agente particular mas também na evolução de agentes de um certo tipo. A cultura que compõe o ambiente de um grupo social cumpre funções não só no desenvolvimento dos agentes mas também na evolução das populações que integram!

Acredito que a abordagem de Tomasello dá sustentação a essa imagem de uma mente estendida, mas ele não explicita isso, ao meu conhecimento, nos seus trabalhos, embora em vários momentos corteje a idéia de uma 'mente de grupo' (group-mindedness; we-ness) associada à intencionalidade conjunta (Tomasello, 2014, p. 5, 80-1, $88,93,152)$.

\section{Conclusão}

Espero ter devidamente qualificado em que sentido o mundo da cultura é um mundo especificamente humano, não somente no sentido de moldar cada um de

\footnotetext{
47 Abrantes, 2006; Abrantes \& Almeida, 2011, p. 283-4.

48 Evidentemente, a escola de Sta. Bárbara não detém o monopólio sobre a expressão 'psicologia evolucionista', que se refere a qualquer teoria que trate da evolução da mente (Dunbar \& Barrett, 2009), a despeito de ser a versão mais conhecida e popular, sobretudo no Brasil.

49 Referências importantes incluem: Clark, 2008, esp. p. 76 et seq.; Gamble et al., 2014, p. 106-7; Audisio, 2017; cf. Shapiro, 2010.
} 
nós no curto tempo ontogenético da nossa existência- que se desenrola nos nichos construídos no tempo histórico de nações e civilizações, uma tese bastante evidente e consensual-, mas que a condição humana foi moldada pela cultura no tempo histórico profundo da filogenia do Homo sapiens e de outras espécies hominínias com as quais compartilhamos ancestrais comuns, perpassando dezenas de milhares de gerações.

De modo menos ortodoxo, podese dizer que a evolução da espécie humana desenrola-se num único tempo histórico, que engloba o desenvolvimento de cada um de nós e a dinâmica das populações, numa sinergia permanente envolvendo processos que vão dos genes aos grupos passando pelos indivíduos, e que se retroalimentam. Esses processos embricados ocorrem em vários níveis ontológicos simultaneamente, que distinguimos para poder compreendê-los com a finitude das nossas mentes (que são produtos desses mesmos processos!), e para os submeter aos procedimentos analíticos da filosofia e das ciências, na esperança de gerar algum conhecimento a esse respeito, para além da estupefação e do maravilhamento de que nos falou, alguma vez, Aristóteles. Para tanto, partimos de imagens de natureza humana enraizadas na nossa experiência ordinária, ainda que incertas e pouco nítidas, e por vezes conseguimos melhor precisálas e, eventualmente, revê-las gerando conhecimento comum e conhecimento científico, que se nutrem mutualmente.

Para quem me acompanhou até aqui, peço licença para introduzir, nesses últimos parágrafos, uma nota mais pessoal. Dei o título "O homem e seus mundos: perspectivas filosóficas e científicas" ao Colóquio em minha homenagem que foi feito na UnB em junho de 2017 e que resultou na publicação deste número da Revista de Filosofia Moderna e Contemporânea. Na abertura do evento relatei que a escolha que havia feito desse título fora motivada, originalmente, pela distinção entre um 'mundo interno' (da mente; da experiência, etc.) e um 'mundo externo' (físico/biológico, social, cultural/simbólico, etc.) e pela intui-

\footnotetext{
50 O conceito de 'mundo' é amplamente usado em Filosofia. Uma pequena lista é sugestiva: mundo material, mundo das idéias, mundo sensível, mundo inteligível, mundo da experiência, três mundos (Popper), mundo subjetivo, mundo objetivo, mundo da vida, visão de mundo, mundos possíveis, a interpretação de muitos-mundos da $\mathrm{MQ}$, etc. Nas pesquisas preliminares que fiz, não encontrei, contudo, um tratamento aprofundado e geral desse conceito e, certamente, ele foi menos explorado do que outros correlatos, como o de 'natureza', por exemplo. O meu colega Róbson Ramos dos Reis, da UFSM, em comunicação pessoal, advertiu-me, contudo, que o conceito de 'mundo' é central na fenomenologia de Husserl (Lebenswelt) e também em Heidegger. Pensando em um título para o evento, o que me veio à mente foi o título de uma coletânea que folheei quando fazia pesquisas no Centro
} 
ção de que alguns aspectos desses mundos fossem exclusiva ou caracteristicamente humanos. ${ }^{50}$

O mundo externo é extremamente diversificado, pois inclui não somente o mundo físico mas também o biológico (outros organismos). Em muitos animais, além disso, o mundo social é de imensa relevância para o seu desenvolvimento e também para a sua aptidão, tendo portanto implicações evolutivas. Esses vários mundos, ou dimensões do mundo desses organismos apresentam, além disso, diferentes graus de complexidade, no sentido que dei ao termo neste artigo.

Em biologia usa-se o conceito de 'ambiente'. O conceito de mundo é mais geral e tem a vantagem de abarcar tanto o que é interno quanto o que é externo a um dado animal, o que o conceito de ambiente não admite, pelo menos como empregado usualmente pelos biólogos. É bem verdade que alguns filósofos se apropriaram desse conceito e estenderam o seu uso. Den- nett, por exemplo, fala do ambiente interno das criaturas popperianas e das gregorianas, por exemplo (1995, p. 374-79).

Que animais têm, além de um mundo externo, também um mundo interno? Não pretendo arriscar uma resposta para esta questão difícil, mas acredito que não possamos tratar o mundo interno daqueles animais que o têm, e o seu mundo externo como independentes. Nem todas as características do ambiente são percebidas por um dado organismo ou relevantes para ele. Além disso, os organismos modificam o seu ambiente em diferentes graus, com implicações tanto para o seu desenvolvimento quanto para a dinâmica da população a que pertencem. De toda forma, a fronteira entre o mundo interno e o mundo externo é móvel. A teoria dos sistemas de desenvolvimento tende, inclusive, a dissolvê-la, como vimos, e também a imagem de uma mente estendida. Os biólogos também usam o conceito de 'nicho' para explicitar es-

\footnotetext{
de Filosofia da Ciência da Universidade de Pittsburgh nos idos dos anos 1980 e que, desde então, ficou submerso nas profundezas do meu inconsciente: Cosmos of Science: Philosophical Problems of the Internal and External Worlds, 1998. Trata-se de uma coleção de ensaios organizada por John Earman e John Norton em homenagem ao filósofo da ciência Adolph Grunbaum, pessoas com quem tive contato bastante próximo à época. Talvez o título dessa coletânea tenha me chamado a atenção por sugerir não só a existência de uma pluralidade de mundos, mas sobretudo por implicar que se esse 'Cosmos' é da ciência então é um produto humano, e não algo completamente depurado dos elementos subjetivos de uma perspectiva humana. Argumento que essa subjetividade, entretanto, não é absoluta na medida em que se trata da perspectiva de uma espécie, de uma população, e não a de um indivíduo particular.

${ }^{51}$ Brandon (1995, p. 47-9) distingue três conceitos de ambiente em biologia: externo, ecológico e seletivo (cf. Sterelny \& Griffiths, 1999, p. 269-272). Nas discussões que faço nesta Conclusão, o conceito de ambiente seletivo é o mais central. O ambiente de desenvolvimento é aquele envolvido na ontogenia dos organismos e Brandon defende que deve ser incorporado ao ambiente seletivo (Brandon, ibid., p. 52).
} 
sas diversas correlações entre o que ção de Umwelt proposta por von é interno e o que é externo a um Uexküll também se situa nessas dado organismo. ${ }^{51} \mathrm{O}$ conceito de cercanias conceituais. Gibson pre'nicho' tem uma rica história e cor- tende, com o conceito de afforresponde, grosso modo, aos ambien- dance, superar a dicotomia subtes ecológico e seletivo de um or- jetivo/objetivo. Eu acrescentaria ganismo. A construção de nichos que uma abordagem evolucionista é um processo que tem importân- e desenvolvimental também tende cia central em vários dos cenários a dissolver a dicotomia entre $\mathrm{o}$ para a evolução humana que discuti neste artigo.

que é particular a um indivíduo e o que é universal em uma es-

Bem depois de ter escrito os parágrafos acima dei-me conta, nas discussões que tivemos no grupo de pesquisa 'Mente, Linguagem e Evolução' (MELE), que J. J. Gibbson (1979) já havia criado um termo, 'affordance', para capturar essas idéias. ${ }^{52}$ Esse termo vem sendo empregado nas mais diversas áreas, inclusive para se pensar a evolução do comportamento. ${ }^{53}$ É difícil ser original em nossos dias... Gibson aproxima, inclusive o volver essas idéias aqui. Isso ficará conceito de 'affordance' do con- para uma outra oportunidade. ceito de 'nicho ecológico'. A nopécie. O mundo da cultura não é somente o mundo em que cada um de nós vive, ou o mundo de um grupo (como os mundos culturais que pesquisam os antropólogos) mas é também, e sobretudo, um mundo da espécie Homo sapiens, e mais uma vez remeto ao título deste ensaio: 'Uma mente embebida na cultura'.

Este artigo já está suficientemente longo e não caberia desenpara uma outra oportunidade.

\footnotetext{
52 Poderíamos tentar traduzir 'affordance' por 'oportunidade', que é oferecida pelo meio ambiente para um organismo de certo tipo; ou o que está à disposição dele e que pode ser aproveitado e explorado por ele no ambiente.

53 Nesse sentido, o artigo de Withagen \& van Wermeskerken (2010) é bastante instrutivo.
} 


\section{Bibliografia}

ABRANTES, P. A psicologia de senso comum em cenários para a evolução da mente humana. Manuscrito - Rev. Int. Fil., Campinas, v. 29, n. 1, p. 185-257, 2006.

. La imagen filosófica de los agentes humanos y la evolución en el linaje homínido. In: Labastida, J. \& Aréchida, V. (orgs.), Identidad y Diferencia. México: Siglo Veintiuno, 2010, p. 331-348.

. Human Evolution: compatibilist approaches. In: Krause, Décio, Videira, Antonio (orgs.), Brazilian Studies in Philosophy and History of Science: an account of recent works. Boston Studies in the Philosophy of Science, Vol. 290, 2011a, p. 171-184.

. Culture and transitions in individuality. In: Dutra, L. H. \& Meyer Luz, A. (orgs.), Temas de Filosofia do Conhecimento. Coleção Rumos da Epistemologia, v. 11. Florianópolis: NEL/UFSC, 2011b, p. 395-408.

Methodological issues in the dual inheritance account of human evolution. In: Martínez- Contreras, J. \& A. Ponce de León A. (eds.), Darwins Evolving Legacy. México, D.F : Siglo XXI editores -Universidad Veracruzana, 2011c, p. 127-143.

Aspectos metodológicos de la teoría de la herencia dual en la evolución humana. In: Martinez-Contreras, J. ; Ponce de Léon, A. (orgs.) Darwin y el evolucionismo contemporáneo. Mexico: Siglo XXI: Universidad Veracruzana, 2012, p. 135-152.

. Human evolution and transitions in individuality. Contrastes, Revista Internacional de Filosofía. Suplemento: Filosofía actual de la biología. Antonio Dieguez y Vicente Claramonte (eds.). Suplemento, v. xviii, 2013a, p. 203-220.

. Evolução humana: estudos filosóficos. Rev. Filos. Aurora (Curitiba), v. 25, n. 36, p. 75-105, jan./jun. 2013 b.

. Linguagem e a evolução da mente humana: a perspectiva de um neurobiólogo. In: Saraiva, P. Cérebro, evolução e linguagem. Brasília: Editora da UnB, 2014a, p. 23-61.

- Natureza e Cultura. In: Abrantes (org.) Ciência E Ambiente, n. 48, jan./jun. 2014b, p. 7-21. Número especial sobre Evolução Humana.

Conflito e cooperação na evolução humana. In: Abrantes (org.) Ciência \& Ambiente, n. 48, jan./jun. 2014c, p. 289-301. Número especial sobre Evolução Humana. 
. Imagens de natureza, imagens de ciência. RJ: EdUERJ, 2016. Evolución cultural. In: Galindo, J. \& Martínez, M. (eds.) Conceptos de la biología evolutiva para las ciencias sociales y las humanidades. México: Universidad Autónoma Metropolitana-Cuajimalpa. No prelo.

ABRANTES, P.; ALMEIDA, F. Evolução humana: a teoria da dupla herança. In: Abrantes (org.), Filosofia da Biologia. Porto Alegre (RS): ARTMED, 2011, p. 261-295.

ALMEIDA, F. Constitution - the evolution of a societal structure - Tese de doutorado defendida na Faculdade de Direito da UnB em 2016.

ALMEIDA, F. ; ABRANTES, P. A teoria da dupla herança e a evolução da moralidade. Principia (Florianópolis), v. 16, n. 1, p. 1-32, 2012. AUDISIO, I. Perspectivas evolutivas sobre la cognición. El compromiso de la hipótesis de la 'mente extendida' com um enfoque biológico evolutivo. Ludus Vitalis, v. XXV, n. 47, p. 141-54, 2017.

BERNAL, C.; ABRANTES, P. Imágenes en la explicación del comportamiento prosocial humano y su evolución. No prelo.

BLACKMORE, S. The meme machine. Oxford: Oxford University Press, 2000.

BOEHM, C. Hierarchy in the forest. Cambridge: Harvard, 1999. . Interactions of culture and natural selection among Pleistocene hunters. In: Levinson, S.; Jaisson, P. (eds.) Evolution and Culture. Cambridge (MA): The MIT Press, 2006, p. 79-103.

BRANDON, Robert N. Adaptation and environment. Princeton (NJ): Princeton University Press, 1995.

BYRNE and WHITEN (eds.) Machiavelian Intelligence. Oxford: Clarendon Press, 1988.

CHENEY, D. L.; SEYFARTH R. M. Baboon metaphysics: the evolution of a social mind. London: The university of Chicago press, 2007.

CLARK, A. Supersizing the mind. Oxford: Oxford University Press, 2008. DARWIN, C. On the Origin of Species by means of Natural Selection. Ontario, Broadview Press, 2003. Editado por Joseph Carroll. . The Descent of Man. Londres: Penguin, 2004.

DEAN et al. Identification of the Social and Cognitive Processes Underlying Human Cumulative Culture. Science, v. 335, p. 11141117, 2012.

DEDIU, D. et al. Cultural evolution of language. In: Richerson, P. \& Christiansen, M. Cultural evolution. Cambridge (MA): The MIT Press, 2013, p. 303-332. 
DENNETT, D. Three kinds of intentional psychology. In: Rosenthal, D. (ed.) The nature of mind. New York: Oxford University Press, 613-633, 1991.

. Darwin's dangerous idea: evolution and the meanings of life. New York: Simon \& Schuster, 1995.

. Two contrasts: folk craft versus folk science, and belief versus opinion. In: Dennett, Brainchildren: essays on designing minds. Cambridge (MA): The MIT Press, 1998, p. 81-94.

DESCOLA, P. Par-delà nature et culture. Paris: Gallimard, 2005.

DUNBAR, R. On the origin of the human mind. In: Carruthers, P.; Chamberlain, A. Evolution and the human mind. Cambridge: Cambridge University Press, 2000, p. 238-253.

DUNBAR, R.; BARRETT, L. Evolutionary psychology in the round. In: Dunbar, R.; Barrett, L. (eds.) The Oxford Handbook of Evolutionary Psychology. Oxford: Oxford University Press, 2009, p. 3-9.

FOLEY, R.; LAHR, M. The anthropological, demographic and ecological context of human evolutionary genetics. In: Donnelly, P. \& Foley, R. (eds), Genes, fossils and behavior: an integrated approach to modern human origins, 2001, p. 223-245.

FOLEY, R.; GAMBLE, C. The ecology of social transitions in human evolution. Phil. Trans. R. Soc. B, v. 364, p. 3267-3279, 2009.

FOLEY, R.; LAHR, M. The evolution of the diversity of cultures. Phil. Trans. R. Soc. B, v. 366, p. 1080-89, 2011.

FUENTES, A. Blurring the biological and social in human becomings. In Ingold, I., \& Palsson, G. (Eds.), Biosocial becomings. Cambridge: Cambridge University Press, 2013, p. 42-58.

GAMBLE, C.; GOWLETT, J.; DUNBAR, R. Thinking big: how the evolution of social life shaped the human mind. Londres: Thames \& Hudson, 2014.

GIBSON J. J. The Ecological Approach to Visual Perception. Boston: Houghton Mifflin, 1979.

GODFREY-SMITH, P. Complexity and the function of mind in nature, Cambridge, Cambridge University Press, 1998.

On the Evolution of Representational and Interpretive Capacities. The Monist, v. 85, n.1: 50-69, 2002.

Folk Psychology under stress: comments on Susan Hurley's 'Animal action in the space of reasons'. Mind E Language, v. 18, n. 3: 266-272, 2003.

On Folk Psychology and Mental Representation. In: H. 
Claping; P. Staines; P. Slezak (eds.), Mental representation. Elsevier, 147-162, 2004.

. Untangling the evolution of mental representation. In:

A. Zilhão (ed.), Cognition, evolution, and rationality: A cognitive science for the XXIst Century. Routledge, 2005, p. 85-102.

. Darwinian populations and natural selection. Oxford: Oxford University Press, 2009.

GOULD, S. J.; LEWONTIN, R. The Spandrels of San Marco and the Panglossian Paradigm: a critique of the adaptationist programme. In: Sober, E. (ed.) Conceptual issues in evolutionary biology. Cambridge (MA):The MIT Press, 1995, pp. 73-90. Publicado originalmente em 1978.

GRIFFITHS, P.; GRAY, R. Developmental Systems and Evolutionary Explanation. In: Hull \& Ruse (eds.) The Philosophy of Biology. Oxford: Oxford University Press, 1988, p. 117-145.

GROVE, M.; PEARCE, E.; DUNBAR, R. I. M. Fission-fusion and the evolution of hominin social systems. Journal of Human Evolution, v. 62, p. 191-200, 2012.

HENRICH, J. Demography and cultural evolution: How adaptive cultural processes can produce maladaptive losses: The tasmanian case. American Antiquity, v. 69, p. 197-214, 2004.

HENRICH, J.; BOYD, R. The evolution of conformist transmission and the emergence of between-group differences. Evolution and $\mathrm{Hu}$ man Behavior, v. 9, p. 215-241, 1998.

HODGSON, G.; KNUDSEN, T. Darwin's conjecture. Chicago: The Univesity of Chicago Press, 2010.

HUMPHREY, N. The social function of intellect. In: Byrne and Whiten (eds.) Machiavelian Intelligence. Oxford: Clarendon Press, 1988, p. 13-26. Publicado originalmente em 1976.

HURFORD, J. The origins of language: a slim guide. New York: Oxford University Press, 2014.

HURLEY, S. Animal action in the space of reasons. Mind $\mathcal{E}$ Language, v. 18, n. 3, p. 231-256, 2003.

INGOLD, T. Introduction to humanity. In Ingold, T. (Ed.), Companion Encyclopedia of Anthropology. Londres: Routledge, 1994, p. 3-13.

- 'People Like Us': the concept of the anatomically modern human. In Ingold, T. The perception of the environment. Essays on livelihood, dwelling and skill (pp. 373-91). London and New York: Routledge, 2000. 
. From the transmission of representation to the education of attention. In: Whitehouse, H. (Ed.), The debated mind: evolutionary psychology versus etnography. Oxford: Berg, 2001, p. 113-153. . Prospect. In: Ingold, T., \& Palsson, G. (Eds.) Biosocial becomings. Cambridge: Cambridge University Press, 2013, p. 121.

KRUPENYE, C. et al. Great apes anticipate that other individuals will act according to false beliefs. Science, v. 354, n. 6308, 6/10/2016, p. 111-14.

LALAND, K. Darwin's unfinished symphony. Princeton: Princeton University Press, 2017.

MALLE, B. The relation between language and theory of mind in development and evolution. In: T. Givón \& B.F. Malle (eds.) The evolution of language out of pre-language. Amsterdam: Benjamins, 2002, p. 265-284.

MARTÍNEZ-CONTRERAS, J. O modelo primatológico de cultura. In: Abrantes, P. (org.), Filosofia da Biologia. RS: ARTMED, 2011, p. 224-240.

MCBREARTY, S.; BROOKS, A. The revolution that wasn't: a new interpretation of the origin of modern human behavior. Journal of Human Evolution v. 39 (5), p. 453-563, 2000.

MITHEN, S. A pré-história da mente. SP: Editora UNESP, 2002. 2005.

. The singing Neanderthals. Londres: Weidenfeld \& Nicolson,

NECO, L.; RICHERSON, P. Was human evolution driven by Pleistocene climate change? In: Abrantes (org.) Ciência E Ambiente, n. 48, jan./jun. 2014, p. 107-17.

NORENZAYAN, A.; HENRICH, J.; SLINGERLAND, E. Religious prosociality: a synthesis. In: Richerson, P. Christiansen, M. (eds.) Cultural evolution: society, technology, language, and religion. Cambridge (MA): The MIT Press, 2013, p. 365-379.

ODLING-SMEE, F. J.; LALAND, K.; FELDMAN, M. Niche construction: the neglected process in evolution. Princeton: Princeton University Press, 2003.

OYAMA, S. On the concept of the anatomically modern human: a discussion on Tim Ingold's 'People like us' (1995): Human History, History or history? Cultural Dynamics, 8, 353-361, 1996.

. The Ontogeny of Information: Developmental Systems and Evolution. Durham: Duke University Press, 2000. 
PIEVANI, T. Between skeptics and adaptationists: new prospects for human language evolution. In: Abrantes (org.) Ciência E Ambiente, n. 48 , jan./jun. 2014, p. 149-63.

PLAZAS, C. ; ROSAS, A. La transición social en el género Homo: de las jerarquías de dominación al igualitarismo. In: Abrantes (org.) Ciência E Ambiente, n. 48, jan./jun. 2014, p. 271-87.

PREMACK, D. ; WOODRUFF, G. Does the chimpanzee have a theory of mind? Behavioral and Brain Sciences, v. 4, p. 515-26, 1978.

QUELLER, D. Cooperators since life began. Quarterly Review of Biology, v. 72, n. 2, p. 184-8, 1997.

REX, R.; ABRANTES, P. Moral nativism: some controversies. Revue Canadienne de Philosophie, v. 56, n. 1, p. 21-44, 2017.

RICHERSON, P.; BOYD, R. Culture is Part of Human Biology: Why the Superorganic Concept Serves the Human Sciences Badly. In: GOODMAN, M. \& MOFFAT, A. (eds.) Probing human origins. Cambridge (MA): The American Academy of Arts and Sciences, 2002, p. 59-85.

. Not by genes alone: how culture transformed human evolution. Chicago: The University of Chicago Press, 2005.

- Rethinking paleoanthropology: A world queerer than we had supposed. In: Hatfield, G. (ed.) Evolution of mind, brain and culture. Philadelphia: University of Pennsylvania Press, 2013, p. 263-302.

RICHERSON, P.; BOYD, R.; HENRICH, J. Cultural Evolution of Human Cooperation. In: Hammerstein, P. (ed.) Genetic and cultural evolution of cooperation. Cambridge: The MIT Press, 2003, p. 357-388.

ROSENBERG, A. Darwinian reductionism: or, how to stop worrying and love molecular biology. Chicago: The University of Chicago Press, 2006.

SEYFARTH, R.; CHENEY, D. Primate social cognition as a precursor to language. In: TALLERMAN, M. \& GIGSON, K. (eds.) The Oxford handbook of language evolution. Oxford: Oxford University Press, 2013, p. 59-70.

SHAPIRO, L. James Bond and the barking dog: evolution and extended cognition. Philosophy of Science, v. 77, 2010, p. 400-418.

SLINGERLAND, E.; HENRICH, J.; NORENZAYAN, A. The evolution of prosocial religions. In: Richerson, P. Christiansen, M. (eds.) Cultural evolution: society, technology, language, and religion. Cambridge (MA): The MIT Press, 2013, p. 335-48. 
SARAIVA, P. Cérebro, evolução e linguagem. Brasília: Editora da UnB, 2014.

SEPÚlVEDA, C.; MEYER, D.; EL-HANI, C. Adaptacionismo. In: Abrantes, P. (org.), Filosofia da Biologia. RS: ARTMED, 2011, p. 162-192. SOBER, E. Philosophy of Biology. Boulder (Colorado): Westview Press, 2000. 2 ed.

SOBER, E. ; WILSON, D. S. Unto Others. Cambridge (MA): Harvard UP, 2003.

SPERBER, D. Metarepresentation in an evolutionary perspective. In: Sperber, D. (org.) Metarepresentations: a multidisciplinary perspective. Oxford: Oxford University Press, 2000, p. 117-137.

STERELNY, K. The evolved apprentice. Cambridge (MA): The MIT Press, 2012.

STERELNY, K.; GRIFFITHS, P. Sex and Death. An introduction to philosophy of biology. Chicago and London: The University of Chicago Press, 1999.

SUDDENDORF, T. The gap: the science of what separates us from other animals. New York: Basic Books, 2011.

TOMASELLO, M. The cultural origins of human cognition. Cambridge \& London: Harvard University Press, 2000.

Origins of human communication. Cambridge (MA): The MIT Press, 2008.

. Why we cooperate. Cambridge (MA): The MIT Press, 2009.

A natural history of human thinking. Cambridge: Harvard University Press, 2014.

WAIZBORT, R.; PORTO, F. Genes, seleção natural e comportamento humano: a mente adaptada da psicologia evolucionista. In: ABRANTES (org.), Filosofia da Biologia. Porto Alegre (RS): ARTMED, 2011, p. $214-260$.

WILSON, D.S.; SOBER, E. Re-introducing group selection to the human behavioral sciences. Behavioral and Brain Sciences, v. 17, p. 332356, 1994.

WITHAGEN, R.; VAN WERMESKERKEN, M. The role of affordances in the evolutionary process considered: a niche construction perspective. Theory and Psychology, v. 20, n. 4, p. 489-510, 2010. 